\title{
Causaliteit in het Nederlandse strafrecht
}

\section{Praeadvies voor de Vereniging voor de vergelijkende studie van het recht van België en Nederland 20I}

\author{
Ad Machielse
}

\section{Inleiding}

Causaliteit is een onderwerp dat ons vertrouwd voorkomt. Causaliteitsvragen in het straf(proces)recht doen zich immers voor in alle onderdelen daarvan. In strafvordering is bijvoorbeeld een belangrijke vraag of een vormverzuim nadeel heeft veroorzaakt, of ambtelijke mededelingen hebben bewerkstelligd dat een rechtsmiddel te laat is ingesteld. In het materiële strafrecht duiken zowel in het Algemeen Deel (AD) als in het Bijzonder Deel (BD) van het Wetboek van Strafrecht (WvS of Sr) causaliteitskwesties op. De ontwikkeling van het denken over causaliteit in het materiële strafrecht concentreert zich echter in het BD. Dan gaat het om de delicten die bestaan in het veroorzaken van een gevolg. Bij die delicten ziet men zich gesteld voor de noodzaak vragen te beantwoorden over verbanden die de strafwet verlangt.

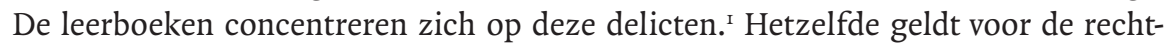
spraak. Maar ook het AD kent causaliteitseisen. Deze zijn echter van een andere orde dan die in het $\mathrm{BD}$. Globaal gesproken gaat het in het $\mathrm{AD}$ om oorzaken van menselijk gedrag en in het BD om de gevolgen daarvan.

De hedendaagse stand van zaken in de Nederlandse wetgeving, rechtspraak en literatuur betreffende de causaliteit in het strafrecht is het resultaat van een ontwikkeling. Kennisneming van die ontwikkeling lijkt mij zinvol. Het WvS heeft zijn vorm en inhoud gekregen in een zoektocht waarin de Code Pénal (Wetboek van Strafregt) een springplank bood naar een eigen nationaal wetboek. Ook is wel inspiratie gevonden in andere rechtsstelsels. Maar de discussies over een nieuw wetboek zijn ook gevoed door andere negentiende-eeuwse wetgeving zoals het Burgerlijk Wetboek (BW) en door opvattingen van gezaghebbende auteurs. Deze achtergrond wordt eerst geschetst. Vanwege de historische concentratie van aandacht voor causaliteitsvragen in het BD lijkt het mij opportuun om dat eerst aan de orde te stellen. Dus komen eerst rechtspraak en literatuur over het $\mathrm{BD}$ en vervolgens het $\mathrm{AD}$ aan

* Hoogleraar straf- en strafprocesrecht aan de Radboud Universiteit Nijmegen en advocaatgeneraal in buitengewone dienst bij de Hoge Raad der Nederlanden.

I M.D. Hazewinkel-Suringa's Inleiding tot de studie van het Nederlandse Strafrecht door mr. J. Remmelink, Deventer I996, I5 ${ }^{\mathrm{e}}$ druk (HSR), p. I74; Mr. J. de Hullu, Materieel Strafrecht, Deventer 20I2, $5^{\mathrm{e}}$ druk, p. 172. 
de orde, telkens voorafgegaan door een bespreking van de totstandkoming van de relevante onderdelen in het WvS.

In het Nederlandse strafrecht is de laatste jaren een discussie op gang gekomen over de plaats en functie van de bakermat van de causaliteitsleren, de condicio sine qua non en de verhouding daarvan tot het criterium der redelijke toerekening. Causaliteit is dus in Nederland een thema met actualiteitswaarde. Die discussie krijgt ruime aandacht.

In het onderstaande zullen niet de afzonderlijke causaliteitsleren als apart item worden besproken. In de leerboeken worden zij uitgelegd. Ik moge volstaan met daarnaar te verwijzen. ${ }^{2}$ Wel zullen auteurs aan bod komen die de discussie over causaliteit hebben vormgegeven of becommentarieerd.

\section{$2 \quad$ Negentiende-eeuwse achtergrond}

\section{I Een filosofisch debat}

In de loop van de ige eeuw werden belangrijke wetenschappelijke ontdekkingen gedaan. Door het toenemend belang van en de belangstelling voor de natuurwetenschappen werden de klassieke filosofische vraagstukken, zoals dat der causaliteit, steeds meer in samenhang gezien met ontwikkelingen in die wetenschappen. ${ }^{3}$ Omdat de natuurwetten werden opgevat als wetten van causaliteit was de causaliteit voorwerp van filosofisch debat. ${ }^{4}$ Dat debat werd in Nederland in de tweede helft van de ige eeuw gevoerd tussen de empiristen en de idealisten. De eersten volgden de stelling dat alle kennis door ervaring ontstaat. Idealisten waren van mening dat kennis en begrip steunen op aangeboren en aprioristische structuren die inherent zijn aan het denkproces. ${ }^{5}$ Cornelis Willem Opzoomer was in de tweede helft van de negentiende eeuw in Nederland de belangrijkste verdediger van het empirisme en degene die de speculatieve metafysica naar het tweede filosofische plan verwees. Hij was overduidelijk schatplichtig aan John Stewart Mill die ook ervaring als enige bron van kennis erkende. ${ }^{6}$ Alleen systematisch empirisch onderzoek, uitgevoerd overeenkomstig de regels van de natuurwetenschappen, genereert volgens Opzoomer kennis.7 Veranderingen ontstaan door veranderende omstandigheden. ${ }^{8}$ Door waarneming en ervaring komt men de regelmatigheid in de natuur op het

2 Voorts is nog steeds lezenswaard G.E. Mulder, Causaliteit in het strafrecht, in Strafrecht in Perspectief, Arnhem I989, p. 179 e.v. waarin de verschillende causaliteitstheorieën bespreking vinden.

3 G.J.L. Scheurwater, Oorzaak en gevolg. Causaliteitsdiscussies in Nederland in de tweede helft van de igde eeuw, dissertatie Maastricht I999, p. I9.

4 Scheurwater, p. I8.

5 Zie voor een korte schets van de tegenstellingen P.J. Zwart, Causaliteit, diss. Nijmegen I967, p. 5 e.v.

6 Scheurwater, p. 3.

7 Scheurwater, p. 22.

8 Scheurwater, p. 29. 
spoor en ontstaat het besef dat onder gelijksoortige omstandigheden gelijksoortige gevolgen optreden. ${ }^{9}$

\subsection{Artikel I283 en I284 BW (oud)}

Tegenwoordig is Opzoomer, die gepromoveerd is in de rechtswetenschap aan de universiteit te Leiden maar hoogleraar filosofie werd aan de Universiteit Utrecht, meer bekend als jurist dan als filosoof. Hij is de auteur van een elfdelig gezaghebbend commentaar op het toenmalig Burgerlijk Wetboek, verschenen in de periode I874-I887, dus in de periode dat het WvS tot stand kwam. Artikel I283 BW (oud) verklaarde de schuldenaar slechts gehouden tot vergoeding van schade die men heeft voorzien of heeft kunnen voorzien ten tijde van het aangaan van de verbintenis, tenzij het aan de arglist van de debiteur te wijten is dat de verbintenis niet is nagekomen.

Artikel I284 had toen de volgende inhoud:

'Zelfs indien het niet nakomen der verbindtenis te wijten is aan de arglist van den schuldenaar moet de vergoeding van kosten, schaden en interessen ten opzigte van de door den schuldeischer geledene schade en de winstderving alleenlijk datgene bevatten hetwelk een onmiddellijk en dadelijk gevolg is van het niet nakomen der verbindtenis.'

De gezaghebbende commentaren op het oud BW waarvan de wetgever van het WvS kennis kon nemen, bieden nauwelijks beschouwingen over causaliteit waarbij de wetgever zou kunnen aansluiten. ${ }^{10}$ Opzoomer schrijft dat de wetgever met de aanduiding van een gevolg als 'onmiddellijk en dadelijk' het verschil tussen oorzaak en aanleiding heeft willen aangeven, maar dat hij dan beter slechts had kunnen spreken van 'een rechtstreeksch gevolg'. ${ }^{\text {II }}$ Nadere verheldering over het verband tussen het niet nakomen van de verbintenis en het ontstaan van schade ontbreekt. Volgens Opzoomer ligt in de causaliteit van de schuldenaar de grond voor de verplichting tot vergoeding van de schade. Waarom de eis van de voorzienbaarheid van de schade dan nog wordt gesteld is hem onduidelijk. ${ }^{12}$

Diephuis vult de eis dat de schade een onmiddellijk en dadelijk gevolg moet zijn van het niet of niet behoorlijk nakomen van de verbintenis aldus in dat het gaat om gevolgen die rechtstreeks en niet door middel van andere bijkomende oorzaken, uit de bedoelde oorzaak voortspruiten. ${ }^{13}$

9 Scheurwater, p. 33 e.v.

Io Enige decennia later is dit wel anders. Zie bijvoorbeeld Mr. J.PH. Suijling, Inleiding tot het Burgerlijk Recht, Haarlem I934, tweede druk, 2e stuk-Ie gedeelte, nr. 35I e.v., waarin een adequatieleer wordt verdedigd.

II Mr. C.W. Opzoomer, Het Burgerlijke Wetboek, Vijfde Deel, Amsterdam I879, p. I04. Elders wordt wel het verschil tussen oorzaak en aanleiding gerelativeerd. Het zou slechts gaan om een kwestie van wat meer of wat minder. Zie Mr. M.K.F. Land, Verklaring van het Burgerlijk Wetboek, Vierde Deel, Haarlem I907, tweede druk herzien door Jhr. mr. W.H. de Savornin Lohman, p. 34 .

I2 Opzoomer, Het Burgerlijk Wetboek, p. I05/Io6.

I3 Mr. G. Diephuis, Het Nederlandsch Burgerlijk Regt, Tiende Deel, Groningen I886, p. I04. 
Ondanks het ontbreken van een duidelijk standpunt van de wetgever van het oud BW over de invulling van de causaliteitsvraag lijkt het mij voor de hand te liggen dat in de laatste decennia van de negentiende eeuw een stilzwijgende empirische invulling daarvan, gelet op het gezag van Opzoomer, de boventoon zal hebben gevoerd.

\subsection{Het Wetboek van Strafregt}

Voordat het WvS tot stand kwam, gold de vertaalde Code Pénal, die met 'stellige wetsvoorschriften' gevolgen aan bepaalde handelingen toerekende. ${ }^{14}$ Een veroordeling voor doodslag (artikel 295 Wetboek van Strafregt) was bijvoorbeeld ook aangewezen als de dood niet was bedoeld of voorzien..$^{15}$ In navolging van de Code Pénal hanteerde het Wetboek van Strafregt een gecompliceerd samengesteld toerekeningsbegrip met niet alleen objectieve maar ook subjectieve elementen. Een afzonderlijk leerstuk van het causaal verband was daarom niet gemakkelijk te ontwikkelen los van het toerekeningsvraagstuk en los van de dwingende bepalingen van de Code Pénal. Voor zover men al niet wordt gedwongen in het keurslijf van de voorschriften van de Code Pénal zal men volgens Van Deinse ter beantwoording van de vraag in hoeverre de gevolgen van een daad kunnen worden toegerekend de algemene rechtsbeginselen te hulp moeten roepen. Toerekenbaar zijn volgens deze auteur de natuurlijke en noodzakelijke gevolgen, waaronder hij verstaat de gevolgen die in een zo nauw verband staan met het misdrijf dat ze daar een geheel van uitmaken en de gevolgen die noodzakelijk uit het gepleegde misdrijf voortvloeien en door de dader moesten worden voorzien. Ook de mogelijke gevolgen zijn toerekenbaar. Niet toerekenbaar zijn daarentegen de toevallige gevolgen die in geen verband staan met het feit, die van de wil van de dader onafhankelijk zijn en die hij niet heeft kunnen en moeten voorzien:

'Zo hangt b.v. bij verwonding, de daarop volgende dood, dikwijls geheel af van bijkomende omstandigheden. Dikwijls hebben daarop den meesten invloed de sterkere of zwakkere ligchaamsgesteldheid van den beleedigde, de meer of min spoedig aangewende geneeskundige hulp, de kunde of onkunde van den geneesheer, goede of slechte behandeling van den geneesheer, goede of slechte verpleging, die de lijder ondervindt bij gezond of ongezond voedsel, goede of slechte ligging, de meerdere of mindere gemakken of gerieflijkheden, welke geldelijke omstandigheden vergunnen, - verder de betrekking, het ambt, de post die bekleed, het beroep of ambacht dat door den lijder uitgeoefend wordt, zijn ijver of luiheid, werkzaamheid of traagheid, goede of kwade wil en honderdlei andere bijzonderheden, waaraan zelfs meerendeels de dader geheel vreemd is.

Wanneer derhalve iemand eenen persoon eene op zich zelve niet doodelijke wonde toebrengt en dezen gedurende den nacht bij het gure weder aan zijn lot overlaat, zoodat daardoor de wonde doodelijk wordt, is het wel niet twijfelachtig, of de dader is ook voor dit laatste verantwoordelijk; doch ten eenenmale onregtskundig zou het daarentegen zijn, indien men hem aansprakelijk stelde voor den

I4 Mr. A.J. van Deinse, De Algemeene Beginselen van Strafregt, ontwikkeld en in verband beschouwd met de Algemeene Bepalingen der Nederlandsche Strafwetgeving, Middelburg I860, § I57 e.v.

I5 Mr. M. Schooneveld, Het Wetboek van Strafregt (Code Pénal) met aantekeningen, 's-Gravenhage I876, 2/295. 
dood, die alleen daaraan is toe te schrijuen, dat de niet direct doodelijk verwonde, aan derden ter verpleging overgegeven zijnde, door dezen aan het gure weder was blootgesteld geworden. ${ }^{16}$

Van Deinse lijkt ook, zij het niet in directe verwijzing naar artikel I284 (oud) BW, een onderscheid te willen aanbevelen tussen directe en verwijderde gevolgen. De laatste zijn doorgaans niet voor de dader voorzienbaar, de eerste wel en daarom zijn de eerste dan ook aan de dader toe te rekenen. Aldus is wel duidelijk dat de auteur evenals het Wetboek van Strafregt, uitgaat van een toerekeningsbegrip waarin subjectieve en objectieve elementen zijn aan te wijzen en dat niet differentieert tussen wederrechtelijkheid en schuld.

\section{Het Wetboek van Strafrecht}

Tijdens de totstandkoming van het WvS was de leer van de condicio sine qua non natuurlijk bekend. Voor het civiele recht had Von Buri deze leer in Duitsland al in de zeventiger jaren van de Ige eeuw verdedigd. Eveneens voor het civiele recht waren er in Duitsland door Von Bar in dezelfde periode aanzetten gedaan voor een adequatietheorie. Maar pas na de totstandkoming van het WvS in I886 werkte Von Kries een adequatietheorie voor het strafrecht uit. Rümelin en Träger publiceerden hun inzichten nog later, zodat de strafwetgever van hun voorstellen om de reikwijdte van de condicio sine qua non in het strafrecht met behulp van een adequatie-eis in te dammen, nog geen kennis kon nemen. ${ }^{17}$ Dit, gevoegd bij het empirisch karakter van de causaliteitsvraag, maakt het niet vreemd dat in de geschiedenis van het WvS nauwelijks verwijzingen naar enigerlei causaliteitsleer zijn te vinden.

\section{I Het Bijzonder Deel}

Bij de bespreking van het BD rezen meer vragen over de invulling van de causaliteit dan bij het AD. Dat is wel begrijpelijk, omdat het BD onder meer strafbaarheid van menselijke gedragingen verbindt aan het ontstaan van een gevolg. Dat was misschien vertrouwder terrein voor de wetgever dan het terrein van de toerekening waar de vrije wil het startpunt der redeneringen was.

De belangrijkste ontboezemingen van de Minister over causaliteit zijn te vinden in de wetsgeschiedenis van artikel $157 \mathrm{Sr}$ dat onder meer de brandstichting met straf bedreigt indien daarvan levensgevaar voor een ander te duchten is en het feit iemands dood ten gevolg heeft. Gemeenschappelijk kenmerk van de misdrijven waardoor de algemene veiligheid van personen of goederen in gevaar wordt gebracht, bijeengebracht in Titel VII waarvan ook artikel 157 Sr deel uitmaakt, is het veroorzaken van een gevaar waarvan hij die het veroorzaakt onmogelijk vooraf de omvang kan

I6 Van Deinse, § I59.

I7 Zie p. I75 e.v.; E.M. Witjens, Strafrechtelijke causaliteit. De redelijke toerekening vergeleken met het privaatrecht, Deventer 20II, p. 2 I4. 
berekenen. ${ }^{18}$ De Minister waarschuwde tegen de neiging om in het artikel te verlangen dat voor verdachte het ontstaan van het gevaar voorzienbaar was. Dat zou een te grote subjectivering betekenen. ${ }^{19}$ De Commissie van Rapporteurs had bezwaren tegen het voorstel. Het zou volgens de Commissie immers meebrengen dat een strafverzwaring verbonden wordt enkel aan de objectieve uitkomst, zonder verband met de wil van de dader. Op zijn minst zou een grotere schuld gepresumeerd moeten kunnen worden. ${ }^{20}$ Ter illustratie gaf de Commissie als voorbeeld de eigenaar van een hooischelf die deze zonder kwade bedoeling in brand steekt, waardoor een daarin slapende bedelaar omkomt. ${ }^{21}$ De Minister wees de opvatting van de Commissie af omdat deze te subjectief zou zijn maar erkende dat een algemene voorzienbaarheid van het gevolg wel nodig was. In een vorige versie van het artikel werd dit tot uitdrukking gebracht door de woorden 'indien daarvan levensgevaar te duchten is' en deze zinsnede nam de Minister alsnog in het voorstel op. ${ }^{22}$ De Commissie hield aanvankelijk voet bij stuk en stelde een amendement voor waarin van het te duchten levensgevaar werd verlangd dat de dader dat had moeten voorzien. ${ }^{23}$

Ook bij de bespreking van het voorgestelde artikel $158 \mathrm{Sr}$, de culpoze brandstichting, werd weer gesproken over de inhoud van de woorden 'ten gevolge heeft'. Het Kamerlid Vening Meinesz vroeg zich af of deze woorden niet ook omvatten het geval dat iemand door het zien van een brand van schrik sterft. Hierop antwoordde de Minister als volgt:

'Ik behoef den geachten afgevaardigde uit Amsterdam wel niet te herinneren dat de woorden "ten gevolge heeft" niet alleen in dit wetsontwerp, maar in vele andere wetten gebezigd worden, en evenmin dat over de beteekenis dezer uitdrukking, meer bepaaldelijk over den omvang der verantwoordelijkheid voor datgene wat door den band der causaliteit met ons handelen verbonden is of beweerd wordt verbonden te zijn, ja over de juridische beteekenis van causaliteit zelve, overal in de regtsgeleerde wereld veel getwist wordt. Wat mij betreft, ik zou nog niet zoo dadelijk toegeven dat het door den heer Vening Meinesz gesteld geval onder dit artikel zal vallen. Maar, hoe dit zij, onbetwistbaar acht ik het, dat geen wetgever het in zijne magt heeft door het kiezen van welke formule ook, de tallooze vragen te voorkomen die het begrip causaliteit in verband met strafregtelijke of civielregtelijke verantwoordelijkheid doet ontstaan. ${ }^{24}$

Voor zover ik zie bevat de geschiedenis van ons WvS geen andere passages waaruit is op te maken hoe Minister en Eerste en Tweede Kamer indertijd de causaliteit hebben ingevuld. ${ }^{25}$

I8 Mr. H.J. Smidt, Geschiedenis van het Wetboek van Strafrecht, Haarlem I88I, Tweede Deel, p. II5.

I9 Smidt, Tweede Deel, p. II6/II7.

20 Smidt, Tweede Deel, p. II8.

2 I Smidt, Tweede Deel, p. IIg.

22 Smidt, Tweede Deel, p. I20.

23 Smidt, Tweede Deel, p. I2I.

24 Smidt, Tweede Deel, p. I36.

25 Simons meent in de Memorie van toelichting op art. 305 van het oorspronkelijk regeringsontwerp een verwijzing naar de artikelen $\mathrm{I}_{2} 83$ en $\mathrm{I} 284 \mathrm{BW}$ (oud) te lezen, waar de Minister spreekt over gevolgen die nooit rechtstreeks te wijten zijn aan het verboden handelen (Prof. mr. D. Simons, Leerboek van het Nederlandsche strafrecht, zesde druk, I937, p. I48), maar 


\subsection{Rechtspraak}

Naar leerstellige aanknopingspunten over de invulling van het causaal verband zal men de eerste decennia na de totstandkoming van het WvS in de rechtspraak van de Hoge Raad tevergeefs zoeken. Als voorbeeld van deze terughoudende opstelling kan gewezen worden op HR 7 juni I9II, W. 9209 waarin een architect en zijn medeverdachte waren veroordeeld voor het aan schuld te wijten zijn van de dood van twee personen. Aan de architect werden vier constructiefouten verweten die tot het instorten van een in aanbouw zijnd gebouw hebben geleid. In cassatie werd geklaagd dat het hof ten onrechte heeft beslist dat voldoende is dat de dader verantwoordelijk is voor een verzuim dat rechtstreeks tot het gevolg heeft meegewerkt, terwijl voor de strafbaarheid het verzuim dat gevolg nu juist moet hebben veroorzaakt. Volgens de Hoge Raad miste het middel feitelijke grondslag, omdat het hof niet slechts heeft geoordeeld dat de verdachte verantwoordelijk was voor verzuimen die tot het onheil hebben meegewerkt maar tevens heeft beslist dat die verzuimen tezamen genomen dat onheil hebben veroorzaakt. De wetgever heeft zich niet uitgesproken over de leer der causaliteit in het strafwetboek. Of er sprake is van een causaal verband is in ieder voorkomend geval overgelaten aan het oordeel van de feitenrechter. En deze heeft aangenomen dat de vier grove verzuimen tezamen tot gevolg hebben gehad dat het gebouw is ingestort waardoor beide werklieden het leven hebben verloren.

Hoewel Simons in zijn noot onder dit arrest erop aandrong dat de Hoge Raad zich eens zou uitspreken is de Raad daarop gedurende lange tijd niet ingegaan. Illustratief is HR 8 april 1929, W. I2004. Verdachte had opzettelijk een ander met de gebalde vuist tegen het rechteroog geslagen. Verdachte werd veroordeeld voor mishandeling, zwaar lichamelijk letsel, namelijk het verlies van het gezichtsvermogen van dat oog, ten gevolge hebbend. In cassatie klaagde verdachte dat dit een abnormaal gevolg was, zodat het vereiste verband tussen de gegeven slag en het verlies van het gezichtsvermogen ontbrak. De Hoge Raad verwees naar de verklaring van het slachtoffer en naar het oordeel van een arts, inhoudende dat de toestand van het oog van het slachtoffer zeer wel kan zijn veroorzaakt door een hevige vuistslag. Het hof heeft hieruit volgens de Hoge Raad kunnen afleiden dat de blindheid aan het rechteroog inderdaad door de mishandeling in het leven is geroepen. De vraag of deze conclusie van het hof terecht is getrokken kan in cassatie niet worden onderzocht. De Hoge Raad laat daar of zo'n zwaar lichamelijk letsel inderdaad als abnormaal moet worden beschouwd en of daarvan de beantwoording van de causaliteitsvraag kan afhangen. In een korte opmerking onder dit arrest vraagt Simons zich af of de Hoge Raad de leer van de adequate veroorzaking hier heeft willen afwijzen. In dat

deze verwijzing is eenmalig en terloops. Naar aanleiding van de discussie over art. $157 \mathrm{sub} 3 \mathrm{Sr}$ maken Polenaar/Heemskerk/Hazelhoff onderscheid tussen middellijke gevolgen van de brand en onmiddellijke, directe of rechtstreekse gevolgen, maar ook zonder deze onderscheidingen te relateren aan enigerlei opvatting over causaliteit; Mrs. K. Hazelhoff, Th. Heemskerk en B.J. Polenaar, Het Wetboek van Strafrecht in doorloopende aanteekeningen verklaard, Eerste Deel, Eerste Boek, Amsterdam I88I, p. I66/I67. Van Brakel schrijft dat aan de Nederlandse noch de Franse wetgeving een bepaalde causaliteitsleer ten grondslag lag; Opmerkingen over causaliteit, W. 12700 . 
geval zou volgens hem een uitgebreidere motivering van pas zijn gekomen. Ikzelf denk dat de Hoge Raad in dit arrest nog maar eens heeft bevestigd dat de vaststelling van een causaal verband een feitelijke kwestie is, overgelaten aan de rechter die over de feiten oordeelt. Het hof heeft klaarblijkelijk geleund op de verklaring van de arts waaruit dit verband voldoende is gebleken.

\subsection{Literatuur}

In de leer- en handboeken van vooraanstaande Nederlandse strafrechtgeleerden die de eerste decennia van de vorige eeuw verschenen, wordt het leerstuk van de causaliteit in het algemeen wel uitgebreid besproken. ${ }^{26}$ Daarbij vormt de condicio sine qua non het uitgangspunt.

Volgens Gewin is een concrete toestand het resultaat van samenwerkende factoren, van welke men er geen kan wegdenken zonder dat ook het resultaat vervalt. Tezamen kunnen deze factoren als de oorzaak van die gebeurtenis worden beschouwd. ${ }^{27}$ Gewin beschrijft het geval van iemand die door een ander wordt verwond, die voor verzorging naar het ziekenhuis gaat en onderweg valt waardoor zijn wond verergert. Door ondeskundige behandeling ontstaat bloedvergiftiging zodat de patiënt sterft. Wat is de oorzaak van zijn dood? Die vraag is verschillend beantwoord. In de nieuwe tijd, zo schrijft Gewin, worden vooral twee standpunten ingenomen. In de eerste plaats het standpunt dat iedere omstandigheid oorzaak is die men niet kan wegdenken zonder dat voorval. Al die oorzaken zijn gelijkwaardig. In de tweede plaats de leer die naar beperking streeft van die oorzaken en op zoek gaat naar de factor die als dé oorzaak heeft te gelden. Men kan een kwantitatief of een kwalitatief onderscheid aanbrengen. Volgens Gewin behoort de adequatietheorie, die als oorzaak aanwijst de omstandigheid die 'ingevolge den geregelden loop der dingen in staat is het gevolg in het leven te roepen', tot de eerste groep. ${ }^{28}$

Ook Van Hamel wijst op de moeilijkheid dat elke gebeurtenis of toestand het noodzakelijke resultaat is van een hoeveelheid samenwerkende factoren, waarvan er niet één kan worden weggedacht zonder dat ook het resultaat, zoals het zich heeft voorgedaan, wegvalt. ${ }^{29}$ De rechtens relevante hoofdvraag is evenwel niet wat de gevolgen zijn maar welke gevolgen iemand heeft te dragen. ${ }^{30}$ De bespreking van de causaliteit wordt volgens Van Hamel gekenmerkt door een grote tegenstelling tussen twee leren. De ene houdt in dat elke factor, die niet kan worden weggedacht zonder dat ook het resultaat vervalt, oorzaak is. Tussen voorwaarde en oorzaak bestaat geen verschil. Vanuit een wetenschappelijke benadering is zij volgens Van Hamel de

26 Dit geldt overigens niet voor Noyon, die in zijn commentaar op het Wetboek van Strafrecht, Arnhem, 1926, in de Inleiding noch elders uitgebreid ingaat op dit onderwerp; Mr. T.J. Noyon, Het Wetboek van Strafrecht, Arnhem 1926. In het commentaar op artikel 157 (Tweede Deel, p. 229) doet deze schrijver blijken dat naar zijn mening van brandstichting alleen gevaar te duchten is in geval van een rechtstreeks, niet van het door omstandigheden van elders middellijk ontstane gevolg.

27 B. Gewin, Beginselen van Strafrecht, Brill I907, p. II3.

28 Gewin, p. II5.

29 G.A. Van Hamel, Inleiding tot de studie van het Nederlandsche Strafrecht, Haarlem I927, p. I9I.

30 Van Hamel, p. 192. 
juiste. Ook in het strafrecht is deze opvatting bruikbaar als een goed ontwikkelde leer van opzet en schuld kan corrigeren. ${ }^{3 \mathrm{I}}$ Opvallend is dat Van Hamel de grenzen van strafrechtelijke aansprakelijkheid in dit opzicht ruim trekt. Zo stelt hij de vraag of degene, die een ander door de bliksem wil laten doden en daartoe meeneemt naar een open veld, niet aan doodslag schuldig is als alles verloopt zoals hij dat heeft gewild. Schuldig aan dood door schuld is volgens hem in ieder geval ook degene die zo'n ongewoon verloop had kunnen en moeten voorzien. Wat betreft de door het gevolg gekwalificeerde delicten merkt de auteur op dat deze categorie niet in het systeem past vanwege het ontbreken van een psychisch element. Als men deze categorie behoudt, biedt de uitgebreidheid van keuze wat betreft kwalificaties en straftoemeting aan de rechter uitkomst in een systeem waarin ook een op ongewone wijze ingetreden gevolg past binnen de causaliteitsleer. ${ }^{32}$ De tweede leer tracht binnen het geheel van noodzakelijke voorwaarden nader onderscheid aan te brengen tussen voorwaarden die niet van belang zijn voor de aansprakelijkheid en voorwaarden die dat juist wel zijn. ${ }^{33}$ De generaliserende of adequatietheorieën zoeken het verschil in de algemene betekenis zoals men die kan leren uit de ervaringsregels. ${ }^{34}$

Van Hamel verwerpt vervolgens de adequatietheorieën. Hij wil vasthouden aan de condicio sine qua non. De vraag is enkel welke andere factoren de aansprakelijkheid beletten. ${ }^{35}$ Van Hamel verdedigt dat de toepassing van de leer van de condicio sine qua non niet op problemen stuit in een stelsel waarin de veroorzaking van het gevolg door schuld beheerst wordt, mits men in het oog houdt dat de kwalificerende gevolgen in het algemeen te voorzien moeten zijn geweest. ${ }^{36}$

De wetgever heeft volgens Van Hamel geen duidelijke opvatting over causaliteit ten grondslag gelegd aan het Wetboek. Dat geldt volgens Van Hamel ook voor de Nederlandse rechtspraak. De beslissingen over de causaliteit zijn casuïstisch. De auteur wijst erop dat bij een culpoos delict vaak de schuldvraag en de causaliteitsvraag in elkaar overlopen, en dat de rechtspraak ook bij de door het gevolg gekwalificeerde delicten onvoldoende onderscheidt tussen de vraag naar de algemene voorzienbaarheid en die van de causaliteit. ${ }^{37}$

Van Hamel bespreekt uitgebreid de problemen in de verhouding tussen causaliteit en nalaten. Dat probleem kan worden verhelderd als men als oorzaak beschouwt iedere toestand die als voorwaarde voor het gevolg niet kan worden weggedacht. Ook het nalaten is een toestand. ${ }^{8}$ Maar niet ieder causaal nalaten brengt strafrechtelijke verantwoordelijkheid mee. Het nalaten moet onrechtmatig zijn en tevens moet er schuldverband zijn. ${ }^{39}$

Evenmin als Van Hamel acht Vos de leer van de condicio sine qua non in het strafrecht onbruikbaar omdat het schuldverband corrigeert waar deze causaliteitsleer

\footnotetext{
Van Hamel, p. I94.

Van Hamel, p. I94.

Van Hamel, p. 195.

Van Hamel, p. I96.

Van Hamel, p. I97.

Van Hamel, p. I99.

Van Hamel, p. 200.

Van Hamel, p. 204.

Van Hamel, p. 205.
} 
ruim uitpakt. ${ }^{40}$ En in de zeldzame gevallen waarin de leer van de condicio sine qua non als oorzaak een normaal gedrag, verricht met een crimineel opzet aanwijst - zoals het geval waarin iemand een ander een treinreis laat maken in de hoop dat de trein ontspoort waardoor de erfenis van de reiziger hem zal toevallen - zal de wederrechtelijkheid ontbreken. ${ }^{4 \mathrm{I}}$ Vos sluit zich ook aan bij de visie van Van Hamel over de door het gevolg gekwalificeerde delicten. Daar is niet alleen een condicio sine qua non vereist maar voorts moet het gevolg in het algemeen voorzienbaar zijn geweest. ${ }^{42}$ Bovendien is er als laatste redmiddel nog het correctief van de avas. ${ }^{43}$ Als twee personen ieder onafhankelijk van elkaar bewerkstelligen dat een bepaald gevolg zal intreden zou men volgens Vos beide gedragingen tezamen als voorwaarde kunnen beschouwen. Dan mankeert het niet aan de causaliteitsleer van Von Buri, maar schiet de deelnemingsregeling tekort. ${ }^{44}$ Vos sluit zich ook aan bij de opvatting van Van Hamel over de causaliteit van het nalaten. Dat is alleen onrechtmatig als het handelen rechtsplicht was. ${ }^{45}$

Volgens Simons is uitgangspunt voor beschouwingen over causaliteit dat iedere gebeurtenis in haar ontstaan wordt beheerst door factoren die tezamen als oorzaak gelden..$^{4}$ Iedere factor afzonderlijk is een voorwaarde voor het gevolg. Voorwaarde voor een gevolg is alles zonder hetwelk dat gevolg niet of niet op die wijze zou zijn ingetreden. De auteur verwijst naar Von Buri volgens wie iedere voorwaarde als oorzaak kan worden aangemerkt en volgens wie alle voorwaarden gelijkwaardig zijn. Simons beschrijft vervolgens de pogingen om deze regel te beperken. Die beperking kan gevonden worden in het onderzoek naar de werking in het speciale geval, maar ook naar de werking in algemene zin. In de eerste benadering moet worden onderzocht welke factor het belangrijkst is geweest voor het ontstaan van het gevolg. Het nadeel van deze benadering is dat men de wording der gebeurtenissen moet kunnen doorgronden, hetgeen meteen het bezwaar voor dit uitgangspunt betekent. ${ }^{47}$ De meer algemeen getoonzette benadering is die der adequate veroorzaking. Er zijn volgens Simons verschillende schakeringen mogelijk, al naargelang men als uitgangspunt neemt de verdachte zelf of een min of meer objectieve criteriumfiguur en of men zich stelt op het tijdstip van handelen voor de vaststelling van het causaal verband, of op een later tijdstip. Hij merkt op dat als er geen correctief is via schuld het vereiste causaal verband slechts onder beperkingen mag worden aangenomen. Die beperking kan volgens Simons het best gevonden worden door alleen van causaal verband te spreken als naar algemene regelen van menselijke ervaring met de mogelijkheid rekening moet worden gehouden dat het gevolg zich uit een bepaalde handeling zou ontwikkelen. Daarbij zal men uit moeten gaan van alle omstandigheden

40 Mr. H.B. Vos, Leerboek van Nederlandsch Strafrecht, Haarlem I947, p. 83.

4I Overigens is het volgens Vos twijfelachtig of dan wel opzet kan worden aangenomen en of men dan niet eerder slechts van een wens kan spreken. Leerboek, p. 83 .

42 Vos, p. 84.

43 Vos, p. 85.

44 Vos, p. 86.

45 Vos, p. 90.

46 Prof. Mr. D. Simons, Leerboek van het Nederlandsche Strafrecht, Groningen-Batavia I937, zesde druk bijgewerkt door prof. Mr. W.P.J. Pompe, nr. 94.

Simons, nr. 95 . 
die in het algemeen of aan verdachte bekend waren of konden zijn. Een onvoorzienbare afloop van een gedraging voorkomt het aannemen van causaal verband. Simons noemt als voorbeeld degene die door mishandeling gewond is geraakt en medische hulp zoekt, maar onderweg daarheen dodelijk wordt geraakt door een vallende dakpan. De verwonding door mishandeling kan niet gelden als oorzaak van de dood.

De vraag naar het causaal verband dient aan de hand van algemene voorzienbaarheid te worden ingevuld niet alleen voor de gevolgen welker ontstaan door opzet of schuld worden beheerst, maar ook voor de strafverzwarende gevolgen. De wetgever kan weliswaar geen wijziging brengen in het natuurlijk causaliteitsbegrip, maar wel kan hij aan dit begrip een beperkte werking toekennen, waardoor het slechts binnen bepaalde grenzen tot strafrechtelijke aansprakelijkheid zal leiden. ${ }^{4}$

\subsection{Civiel intermezzo}

Causaal verband en onrechtmatige daad

In civiele zaken huldigde de Hoge Raad oorspronkelijk ook het standpunt dat de wet geen regels stelt met betrekking tot de relatie tussen schade en onrechtmatige daad, zodat het oordeel over die relatie aan het vrije oordeel van de feitenrechter is overgelaten.49 Maar in 1927 heeft de civiele kamer van de Hoge Raad doen blijken dat vragen naar causaal verband ook rechtsvragen kunnen zijn. In HR 3 februari I927, W.II645 betichtte eiser gedaagden ervan verantwoordelijk te zijn voor de publicatie in De Haagsche Post van een open brief over de toestand ener NV, in welke brief in strijd met de waarheid ongunstige berichten waren gepubliceerd, waardoor eiser, vrezend dat zijn aandelen in die NV waardeloos zouden worden, die met verlies heeft verkocht. Enige tijd nadien herstelde de koers zich. De rechtbank had geoordeeld dat eiser niet heeft gesteld dat de verkoop van zijn aandelen noodzakelijk was. Onder die omstandigheden ontbrak het verband tussen de publicatie en het door eiser geleden verlies, dat slechts het gevolg is geweest van een onjuist inzicht van eiser over het verwachte beursverloop. De Hoge Raad oordeelde evenwel dat de rechtbank te zware eisen had gesteld, door voor aansprakelijkheid van gedaagden te verlangen dat de eiser in de noodzakelijkheid had verkeerd om zijn aandelen te verkopen. Onder de door eiser gestelde omstandigheden was de schade, door hem geleden als gevolg van de verkoop van de aandelen tijdens de tijdelijke koersdaling, het rechtstreeks en onmiddellijk gevolg van de handeling die de tijdelijke daling in het leven riep. Dat is niet alleen zo wanneer de verkoop noodzakelijk was, maar ook wanneer de verkoop, ofschoon vrijwillig geschied, het redelijkerwijs te verwachten gevolg was van de gepleegde handeling. ${ }^{\circ}$ De woorden die de Hoge Raad hier gebruikt, lijken geïnspireerd door artikel I284 BW (oud).

48 Simons, nr. 98 .

49 Zo oordeelde de Raad bijv. in HR 23 juni I922, W. Io948 over een schadeclaim na een onrechtmatig geoordeeld derdenbeslag op aandelen.

50 Zie ook HR II december I93I, W.I2386 waarin de Hoge Raad de kwestie die in cassatie voorlag aldus formuleerde dat het de vraag was of de geleden schade het redelijkerwijs te verwachten gevolg was van de publicatie van de juiste stukken van de onderneming. Indertijd toetste de 
De artikelen $\mathrm{I} 283$ en $\mathrm{I}_{2} 84 \mathrm{BW}$ (oud) bepaalden dat alleen die schade voor vergoeding na wanprestatie in aanmerking kwam die een onmiddellijk en dadelijk gevolg van de wanprestatie was en die men heeft voorzien of heeft kunnen voorzien ten tijde van het aangaan van de verbintenis, tenzij de wanprestatie aan arglist te wijten was. Ten tijde van het totstandkomen van het WvS was rechtspraak van de Hoge Raad over deze artikelen voorhanden, waaruit evenwel niet kon blijken dat de Hoge Raad aan zijn oordelen een bepaalde causaliteitstheorie ten grondslag legde. De Hoge Raad beperkte zich tot een toetsing aan de inhoud van de artikelen I 283 en I284. Zie HR I8 december I884, W. 5I22 waarin de Hoge Raad overwoog dat het BW wel inhield dat in het algemeen alleen die schade moet worden vergoed die men tijdens het aangaan van de verbintenis heeft voorzien of heeft kunnen voorzien en die een onmiddellijk en dadelijk gevolg van de wanprestatie is, maar niet bepaalde welke elementen als maatstaf voor de berekening van de schade hebben te gelden en dat daarom de beslissing van de rechter wat als maatstaf in aanmerking komt feitelijk is en in cassatie moet worden geëerbiedigd..$^{\text {I }}$

Maar ook hier lijkt I927 het jaar van de ommekeer te zijn. In HR I8 februari I927, W. II636 overwoog de Hoge Raad dat de schade is het naar ervaringsregels als niet onwaarschijnlijk te verwachten en dus onmiddellijk gevolg van de wanprestatie die erin had bestaan dat een ondergeschikte van de spoorwegmaatschappij na weging van de vracht een te laag gewicht in de originele vrachtbrief had vermeld, waardoor de verkoper minder uitbetaald kreeg van de koper. Hoewel de wet al een aanwijzing inhield door - behoudens bij arglistige wanprestatie - voorzienbaarheid te verlangen van de schade ten tijde van het aangaan van de verbintenis wordt hier de voorzienbaarheid van de schade nadrukkelijk gekoppeld aan de redelijke verwachting tijdens de wanprestatie.

\subsection{De Hoge Raad gaat differentiëren}

In de twintiger en dertiger jaren van de vorige eeuw is de strafkamer van de Hoge Raad allengs gaan winkelen bij verschillende opvattingen over causaliteit. Zo heeft de Hoge Raad het causaal verband wel louter met behulp van de condicio sine qua non onderbouwd in HR II januari 1937 , NJ I937, 675. Verdachte was op de verkeerde weghelft tegen een motorrijder gebotst, die daarna overleed. De Hoge Raad overwoog dat het bewezen verklaarde causaal verband uit de bewijsmiddelen kon worden afgeleid omdat van een aanrijding geen sprake zou zijn geweest als verdachte op het voor hem bestemde rechter weggedeelte zou zijn gebleven. Ook heeft hij

Hoge Raad het verband tussen onrechtmatige daad en schade ook wel aan het criterium van de ervaringsregelen (HR 28 februari I929, W. II958).

5I Zie ook HR I2 maart I880, W. 4486, waarin het hof volgens de HR terecht heeft getoetst of de schade was 'geleden regtstreeks ten gevolge van wanpraestatie der eischende firma' en HR Io juni I88I, W. 4649, waarin de HR over schade door wanprestatie van de huurder overwoog dat deze 'niet bepaald gelegen [is] buiten den gewonen loop der zaken' en daarom voorzienbaar was. 
aansluiting gezocht bij het BW, bijvoorbeeld in HR 6 juni 1933, NJ 1933, p. I299. Verdachte had in een bocht ingehaald terwijl naast hem een tram reed. De auto van verdachte kwam in botsing met een tegemoetkomend motorrijwiel. De passagier van de motor is daarbij op de trambaan terechtgekomen en door de tram overreden. Volgens de Hoge Raad heeft het hof kunnen overwegen dat de overrijding door de tram en de dood van de passagier 'een onmiddellijk en rechtstreeksch gevolg waren van de aanrijding en den val, daar zonder deze aanrijding de overrijding door de tram niet zou hebben plaats gehad (...)'. In deze zin worden de condicio sine qua non en artikel I284 BW (oud) op een eigenaardige manier met elkaar verknoopt, omdat het zijn van een condicio sine qua non zonder meer ertoe lijkt te leiden dat er sprake is van een 'onmiddellijk en rechtstreeks' gevolg.

Soms heeft de Hoge Raad wel geleund op de bewoordingen die Paul Scholten gebruikte voor de aanduiding van het relevante causaal verband. In HR I7 december 1934 , NJ I935, p. 320 overwoog de Hoge Raad dat het hof heeft kunnen aannemen dat het op zo korte afstand voorbijrijden van een fietser zoals verdachte heeft gedaan, de kans heeft vergroot dat de aanrijding zou volgen en dat deze wijze van inhalen aldus tot de ook werkelijk gevolgde aanrijding heeft meegewerkt. En in HR I5 oktober 1934, NJ 1934, p. I544, heeft de Hoge Raad geoordeeld dat het onverlicht laten staan van een kapotte vrachtwagen op de weg naar ervaringsregels een begunstigende factor is voor het niet tijdig daarvan opmerken door een andere weggebruiker. Hier sprak de Hoge Raad van wat ervaringsregels ons leren, hetgeen een verwijzing is naar een adequatieleer.

\subsection{Condicio sine qua non in feitenrechtspraak}

De rechtspraak van de feitenrechter biedt voorbeelden van toepassing van de condicio sine qua non om een causaal verband te onderbouwen. In het vonnis van de Rechtbank Middelburg van Io maart I89I, W. 6025, had verdachte zijn revolver schoongemaakt en was bezig deze weer in elkaar te zetten toen het schot viel waardoor zijn op een meter afstand gezeten 8I-jarige blinde en dove schoonmoeder in haar hoofd werd getroffen. Enige dagen nadien overleed zij. Deskundigen beoordeelden de wijze waarop verdachte te werk was gegaan als zeer onvoorzichtig. Medisch deskundigen verklaarden ter terechtzitting dat de kogel niet de beschadiging van de hersenen teweeg kan hebben gebracht die zij bij hun onderzoek hebben geconstateerd. De schade die de kogel heeft aangericht is waarschijnlijk vergroot door een onbekende oorzaak die kan hebben bestaan in een hoestbui van de overledene. Maar die onbekende omstandigheid zou zeker niet de dood ten gevolge hebben gehad 'indien niet de kogel de hersenmassa gedeeltelijk had verwoest en ene bloeding daar ter plaatse had veroorzaakt'. De rechtbank nam deze resultaten van het onderzoek van de medisch deskundigen over en veroordeelde verdachte voor dood door schuld. Ook al mocht een onbekend gebleven omstandigheid aan de dood van het slachtoffer hebben meegewerkt moet toch de dood als gevolg van een verwonding door het schot worden aangemerkt. Als de schotwond niet zou zijn toegebracht zou het gevolg, de dood, niet zijn bewerkstelligd door de onbekende omstandigheid die de gevolgen van het schot in concreto heeft verergerd. 
In het vonnis van Rechtbank 's-Gravenhage I9 juli I9I9, NJ I9I9, p. I309 moest de rechtbank de vraag beantwoorden of een drogist schuldig was aan de dood van een kind. Een arts had geadviseerd om aan een ziek kind een mengsel te geven van fosfor en levertraan, maar verstrekte daartoe geen recept, noch gaf hij de waarschuwing dat het toedienen van een te geconcentreerde dosis voor een kind levensgevaarlijk is. Daarop wendden de ouders zich tot een drogist bij wie men zonder recept terechtkon. De drogist had nog fosforlevertraan in voorraad, bestemd voor honden, en gaf dat zonder vragen mee. De dosering bleek lethaal voor het kind. De rechtbank veroordeelde de drogist en overwoog 'dat, had beklaagde de fosforlevertraan niet afgeleverd, deze niet aan het kind had kunnen worden toegediend, en het kind niet tengevolge van dat gebruik zoude zijn gestorven, zodat de aflevering door beklaagde is geweest de oorzaak van de dood'.

\subsection{Causa proxima in feitenrechtspraak}

Wanneer meerdere factoren een bijdrage hebben geleverd aan het ontstaan van een gevolg en wanneer de vraag rijst welke van de factoren tot strafrechtelijke aansprakelijkheid moet(en) leiden, is het verleidelijk om op zoek te gaan naar de causa proxima, die in een direct verband staat met het gevolg. Incidenteel zijn in de strafrechtspraak wel voorbeelden te vinden van inspiratie door de eis in artikel I284 BW (oud) van een 'onmiddellijk en dadelijk' verband, waarin de gedachte aan de causa proxima tot uitdrukking komt. Het bekendst is de zogenoemde slagkwikpijpjessententie van het Hoog Militair Gerechtshof.52 Een luitenant, gedetacheerd bij de handgranatenschool, had onderdelen van handgranaten waaronder slagkwikpijpjes, naar zijn pension meegenomen. Hij had zijn hospita gezegd dat deze slagkwikpijpjes gevaarlijk waren. Bij zijn vertrek uit het pension liet hij de pijpjes in een vaasje op de schoorsteenmantel achter. Kort na zijn vertrek overleed de hospita en aangezien haar dochter toen het vaasje wilde meenemen haalde zij die pijpjes eruit en liet die op de schoorsteenmantel liggen. Een bewoonster gebruikte een pijpje om een raampin te vervangen. Toen ook zij was vertrokken, kregen twee werklieden opdracht de ramen en de deuren te inspecteren. Een van hen vond het pijpje dat als raampin diende en ging er, om de hardheid ervan te controleren, met een hoedenspeld in peuteren. Er volgde een ontploffing waarbij beide werklieden ernstig werden gewond. De ter zake van 'zwaar lichamelijk letsel veroorzaakt door schuld' vervolgde luitenant werd door het HMG vrijgesproken, omdat het causaal verband ontbrak, nu er geen onmiddellijk en dadelijk verband was tussen de onvoorzichtigheid en het gevolg.

Ook middels andere bewoordingen dan het 'onmiddellijk en dadelijk' drukte de feitenrechter zich uit op een wijze die doet vermoeden dat voor hem beslissend is geweest of het gedrag van verdachte een causa proxima was.

De Rechtbank Dordrecht bijvoorbeeld sprak de kapitein van een stoomboot vrij van het veroorzaken van lichamelijk letsel door schuld omdat, vanwege de roekeloze 
wijze waarop de gekwetste zich zelf aan het gevaar heeft blootgesteld, het lichamelijk letsel is te beschouwen als een meer verwijderd en niet noodzakelijk gevolg van de onvoorzichtige handeling van verdachte. ${ }^{53}$

\section{Adequatieleren}

Met horten en stoten kreeg in de dertiger jaren de adequatieleer vaste grond onder de voeten. Algemene voorzienbaarheid, waarschijnlijkheid, het te verwachten zijn, ervaringsregels; dit zijn de termen waarmee de rechtspraak vragen over het causaal verband te lijf begon te gaan.

\section{I Rechtspraak}

In het algemeen kristalliseerde allengs de opvatting uit dat het moet gaan om een redelijke voorzienbaarheid zoals door Träger bepleit. Wat mocht de verstandige mens gelet op hetgeen hem bekend en kenbaar was verwachten? Illustratief voor de opmars van de adequatieleren is HR 30 oktober I933, NJ I933, p. I777 m.nt. Pompe. Het betreft de veroordeling voor dood en letsel, aan schuld te wijten, van een automobilist die, na het passeren van de brug over de Tweemolentjesvaart, onvoldoende was uitgeweken voor een tegenligger. Een aanrijding volgde waarna verdachte met zijn auto in het water terechtkwam. Een inzittende van zijn auto overleed en een andere inzittende raakte gewond. De cassatieschriftuur klaagde over het causaal verband tussen de aanrijding en de gevolgen. De Hoge Raad verwierp het middel omdat het hof kon aannemen dat door de aanrijding verdachtes auto tegen verschillende objecten is aangebotst en te water is geraakt en de dood en het letsel van de inzittenden voorzienbare gevolgen waren van het roekeloze rijden van verdachte. Iedereen die een auto bestuurt, kan immers bij onvoldoende uitwijken voor een tegenligger niet alleen voorzien dat zijn auto met de tegenligger in aanrijding zal komen, maar ook dat door de aanrijding de auto het gevaar loopt te gaan slingeren, in aanraking te komen met andere objecten en in een langs de weg lopende vaart terecht te komen met uiteraard voor de inzittenden alleszins waarschijnlijk noodlottige gevolgen. Het arrest van 30 oktober 1933 is een voorbode van een nieuw tijdperk waarin de Hoge Raad niet alleen zelf nagaat of de feitenrechter een juiste uitleg heeft gegeven aan de wet, voor zover deze een causaal verband verlangt, maar ook het causaal verband invult. Het moet gaan om gebeurtenissen die een redelijkerwijs te verwachten gevolg van het handelen zijn, die naar algemene ervaringsregels daardoor worden veroorzaakt. Als sterk staaltje van deze rechtspraak geldt HR I3 januari I970, NJ 1970, I44, waarin het causaal verband tussen het verkeersgedrag van verdachte en het overlijden van een voetgangster ter discussie stond. Verdachte reed met hoge snelheid en gladde banden over een natte weg met tramrails. Hij raakte in een slip en botste tegen een verkeerszuil, waardoor de auto kantelde en op zijn dak 
doorschoof. De auto raakte een voetganger die door een etalageruit werd geworpen. Een zich op het trottoir bevindende vrouw werd door het vallend glas geraakt en overleed door bloedverlies. In cassatie werd erover geklaagd dat het hof had bewezenverklaard dat de dood van de vrouw door de aanrijding of botsing is veroorzaakt. In de voetsporen van A-G Remmelink besliste de Hoge Raad dat uit de bewijsmiddelen kon volgen dat er oorzakelijk verband was tussen de bewezenverklaarde botsing en de dood van de vrouw. Naar algemene ervaringsregels is de bewezenverklaarde reeks van gebeurtenissen, volgend op de botsing, te rekenen tot wat als gevolg van zo'n botsing van een auto die met ongeveer $70 \mathrm{~km} / \mathrm{h}$ slipt tegen een verkeerszuil, redelijkerwijs is te voorzien.

Een ander opmerkelijk voorbeeld levert het vonnis van de Rechtbank Utrecht van I8 januari I949, NJ 1949, 665, waarin een knecht van een veerpont werd beschuldigd van dood door schuld. Verdachte had verzuimd de slagboom van de pont ter rivierzijde te laten zakken. Een fietser reed hard de dijk af, over de pont de rivier in en verdronk. De rechtbank overwoog dat het verzuim van de knecht wel een voorwaarde was voor het te water raken van het slachtoffer maar niet de oorzaak, omdat onder deze omstandigheden niet als redelijkerwijs te verwachten gevolg van verdachtes verzuim was te beschouwen dat de wielrijder niet eigener beweging tijdig op de pont zou stoppen. Dit vonnis is een typisch voorbeeld van de toepassing van de adequatieleer. Eerst stelt de rechtbank vast dat er een condicio sine qua non-verband is maar door een adequatiebeperking kon niet worden bewezen dat de dood aan de schuld van verdachte te wijten was. Klaarblijkelijk is de rechtbank uitgegaan van de gedachte dat als de afsluitboom wel zou zijn gesloten de fietser op tijd zou zijn gestopt. De rechtbank is kennelijk er voorts van uitgegaan dat ook in de leer van de condicio sine qua non een nalaten de voorwaarde kan zijn voor het intreden van een gevolg. Het causaal verband tussen het verzuim van de knecht en de dood van de fietser is onderbroken door de fout van de fietser waarmee in redelijkheid geen rekening behoefde te worden gehouden.

Incidenteel zijn er overigens ook andere invullingen, met name de opvatting van Rümelin volgend, die een redelijke voorzienbaarheid als eis stelde maar dan op basis van alles wat naderhand bekend is geworden. De terminologie die dan opgeld doet, is dat het handelen 'geschikt en voorbestemd' is om het gevolg teweeg te brengen. Het botsen met een auto tegen een boom is bijvoorbeeld een wijze van rijden die 'geschikt en voorbestemd' is om aan een inzittende dodelijk letsel toe te brengen. ${ }^{54}$

Het bekendste voorbeeld van een navolging van Rümelin biedt een arrest van het Hof Amsterdam van I4 juli I939, NJ I940, 34, het zogenoemde pantoffel-eierschaalschedelarrest. Verdachte had opzettelijk en met grote kracht van een geringe afstand zijn pantoffel tegen het hoofd van zijn echtgenote gegooid. Zij werd daardoor op haar rechterslaap getroffen en is kort nadien aan haar verwondingen overleden. De rechtbank veroordeelde verdachte enkel voor mishandeling. Het causaal verband tussen de mishandeling en het overlijden achtte de rechtbank niet bewezen omdat een worp met een pantoffel zoals die van verdachte niet geschikt en voorbestemd 
zou zijn om de dood te veroorzaken. Evenmin zou de dood het voorzienbaar gevolg zijn van zo een worp. De rechtbank wees op het verslag van een deskundige inhoudende dat de schedel van de vrouw ongewoon dun was met name in de rechterslaapstreek, maar dat de worp met een pantoffel een normale schedel niet zo zou hebben kunnen beschadigen. De verdediging voerde in hoger beroep aan dat de dood van de vrouw niet het voorzienbaar gevolg van de worp is geweest. Het hof overwoog dat de advocaat over het hoofd zag dat gelet moet worden op alle omstandigheden zoals zij zich in het bijzonder geval hebben voorgedaan en dat een worp met een van zo een zool en hak voorziene pantoffel in dit geval, nu de vrouw een abnormaal dunne schedel had die niet bestand was tegen de gewelddadige worp, geschikt en voorbestemd was om de dood van de vrouw te veroorzaken omdat naar de normale gang van zaken te verwachten was dat haar schedel zou bezwijken, met als waarschijnlijk gevolg haar dood.

\subsection{Tussenkomende factoren}

Causaal verband tussen een gedraging en een gevolg kan betwist worden als tussenkomende factoren een rol hebben gespeeld. Te denken is aan omstandigheden van de kant van het slachtoffer, maar ook aan inwerkingen door derden. De Hoge Raad toonde zich niet toeschietelijk om in zo een geval doorbreking van het adequate causaal verband aan te nemen.

Voorzienbaarheid en verborgen lichamelijke kwetsbaarheden

Verborgen lichamelijke kwetsbaarheden leveren voor het vaststellen van causaal verband geen problemen op bij de door het gevolg gekwalificeerde delicten noch bij de doleuze en culpoze delicten. In HR 24 januari 1950, NJ 1950, 293 was verdachte veroordeeld voor een mishandeling, zwaar lichamelijk letsel ten gevolge hebbend. Verdachte had een ander met een koperen buis op het hoofd geslagen. Na de slag werd het slachtoffer getroffen door een verlamming van linkerarm en -been en doofheid aan een oor. Het causaal verband tussen de handelingen van verdachte en het zwaar lichamelijk letsel werd betwist omdat het letsel samenhing met de buitengewone omstandigheid dat dit slachtoffer een ongewoon zwakke schedel had. De Hoge Raad verwierp echter het cassatieberoep omdat van het slaan 'met een koperen buis zodanig letsel te verwachten was ook bij een niet dunne schedel'.

Voor de opzetdelicten wijs ik op HR 8 juni I97I, NJ I972, 90 m.nt. Bronkhorst waarin verdachte in een koude winternacht het dronken slachtoffer in een verlaten omgeving uit een auto gesleurd had, geslagen en geschopt, de kleren van het lijf gerukt en daar had achtergelaten. De volgende dag is het stoffelijk overschot van het slachtoffer aangetroffen. Verdachte werd veroordeeld voor doodslag. Het hof verwierp het verweer over het ontbreken van causaal verband tussen het handelen van verdachte en de dood van het slachtoffer, welke verwerping voorzien was van een ruime motivering waarin de redelijke verwachting centraal stond en waarin het hof ook overwoog dat daaraan niet afdoet dat bij het slachtoffer hartafwijkingen zijn vastgesteld. In cassatie overwoog de Hoge Raad dat uit de bewijsconstructie kan volgen dat de gedragingen van verdachte de gezondheid van het slachtoffer aan een 
zo ernstig gevaar hebben blootgesteld dat de kort daarop ingetreden dood van het slachtoffer, ook indien deze niet aan een hartafwijking zou hebben geleden, als een redelijkerwijs te verwachten gevolg van die gedragingen kan worden aangemerkt.

Een bevestiging van de relativering van een 'verborgen gebrek' aan het slachtoffer maar dan bij de culpoze delicten levert HR 27 november I962, NJ I963, 513 (Binckhorstlaan). Verdachte sloeg met zijn Solex op de Binckhorstlaan in Den Haag linksaf. Daarbij belemmerde hij de doorgang voor een hem tegemoetkomende bromfiets. De andere bestuurder botste tegen de Solex, vloog over het stuur en viel op de rijbaan. Hij overleed aan hersenletsel. De verdediging had aangevoerd dat de dood van het slachtoffer niet aan verdachtes schuld te wijten was, omdat de schedel van het slachtoffer dunner was dan normaal en dit voor verdachte niet voorzienbaar was. Het hof antwoordde dat de dood in het algemeen het voorzienbaar gevolg is van een aanrijding tussen bromfietsen van zodanige aard dat een van de bestuurders over het stuur schiet en vervolgens op straat valt en dat hieraan niet afdoet dat de gevolgen van de aanrijding mede zijn veroorzaakt door de abnormaal dunne schedel van het slachtoffer. Volgens de Hoge Raad was het algemeen voorzienbaar dat een bestuurder van een bromfiets die met $30 \mathrm{~km} / \mathrm{h}$ wordt gestuit door een andere bromfiets daarbij over het stuur van zijn bromfiets zal schieten en op de weg zal vallen. Uit de bewezen toedracht van de aanrijding heeft het hof kunnen aannemen dat de dood van het slachtoffer een in het algemeen voorzienbaar gevolg van de aanrijding was. Nu het hof deze voorzienbaarheid heeft kunnen aannemen kan in cassatie niet worden onderzocht of het hof daarbij ook andere feiten, zoals de abnormale kwetsbaarheid van de schedel van het slachtoffer in aanmerking had moeten nemen.

Kortom, door bij verborgen lichamelijke kwetsbaarheden een ruime voorzienbaarheid aan te nemen komt toepassing van de leer van Träger tot dezelfde resultaten als die van Rümelin.

\section{Voorzienbaarheid en eigen schuld van het slachtoffer}

De eigen schuld van het slachtoffer van een culpoos delict doet volgens vaste rechtspraak van de Hoge Raad uit de eerste helft van de twintigste eeuw niets af aan de oorzakelijkheid van het onvoorzichtig gedrag van de verdachte. 55 De artikelen 307 en $308 \mathrm{Sr}$ stellen slechts als eis dat verdachtes onvoorzichtig gedrag een der oorzaken van letsel of dood is geweest. ${ }^{6}$ De mogelijkheid dat het gevolg misschien nog te vermijden was geweest als het slachtoffer op een andere wijze had gereageerd doet er niet toe..$^{57}$ Hetzelfde geldt wanneer het slachtoffer door tijdig medische hulp in te roepen de gevolgen van het handelen van verdachte misschien nog had kunnen

55 HR 2 januari I923, NJ I923, p. 456; HR II maart I935, NJ I935, p. 7I4; HR 7 februari I938, NJ I938, $9 \mathrm{I} 8$.

56 HR 24 maart I924, NJ I924, p. 735; HR I4 juni 1926, NJ I926, p. 740. Overigens worden bij de culpoze delicten de discussies over andermans schuld die oorzaak zou zijn van het gevolg meestal gevoerd in de ring van de culpa. Zie bijvoorbeeld HR I mei I973, NJ I973, 399 m.nt. Van Veen.

57 HR II maart I935, NJ I935, p. 7I4. 
voorkomen. ${ }^{8}$ Het ligt niet voor de hand om bij andere materieel omschreven delictsgroepen hier anders over te denken.

Het wekt daarom geen verbazing dat ook niet-verstandige beslissingen van het slachtoffer het causaal verband tussen een gevaarlijk handelen van verdachte en een te verwachten gevolg niet zullen doorbreken. Een bekend voorbeeld in de Nederlandse rechtspraak daarvan is HR 20 april I97I, NJ I972, 82. Verdachte was met zijn auto achter tegen een voor een gesloten spoorwegovergang wachtende auto gebotst, waardoor deze auto op de spoorwegovergang belandde. De bestuurder van die auto probeerde zijn vrouw en kind uit de auto te redden, werd daarbij gegrepen door de trein en liep ernstige verwondingen op. Verdachte betoogde dat dat letsel niet aan zijn schuld te wijten was omdat de bestuurder zich in veiligheid had kunnen brengen, maar dat niet heeft gedaan om zijn vrouw en dochter uit de auto te halen. Het hof had dit verweer verworpen omdat de bestuurder redelijkerwijs en menselijkerwijs niet anders kon handelen en zijn letsel een normaal uitvloeisel was van de botsing, door verdachte veroorzaakt. Daaraan deed volgens het hof niet af dat achteraf zou kunnen worden vastgesteld dat vrouw en dochter van de bestuurder ook ongedeerd zouden zijn gebleven als de bestuurder zichzelf tijdig in veiligheid had gebracht. De Hoge Raad overwoog dat ook als de bestuurder voldoende gelegenheid zou hebben gehad om zijn auto tijdig van de spoorbaan te rijden het gedrag van het slachtoffer naar algemene ervaringsregels is te rekenen tot hetgeen als gevolg van een aanrijding, waardoor iemand in een schrikwekkende positie wordt gebracht, redelijkerwijs is te voorzien. Bronkhorst schrijft in zijn noot onder dit arrest dat de vraag naar de voorzienbaarheid vele antwoorden kent en dat deze vraagstelling niet meer is dan een schijnprobleemstelling achteraf, waar het eigenlijk gaat om een redelijke en zedelijk te verantwoorden keuze van aansprakelijkheid.

\subsection{Literatuur}

De adequatieleren zoals door de auteurs verwoord, vertrekken vanuit de condicio sine qua non. Van Hattum bijvoorbeeld schrijft dat het bewijs van causaal verband alleen bestaat als tussen opeenvolgende gebeurtenissen onderlinge afhankelijkheid bestaat zodanig, dat bij het ontbreken van een van die gebeurtenissen onder overigens gelijke omstandigheden het gevolg niet kan intreden.59 Bezwaar tegen deze leer is de eindeloze reeks oorzaken, met name bij de door het gevolg gekwalificeerde delicten. Het consequent toepassen van de condicio sine qua non leidt daar tot onaanvaardbare resultaten. Zij zouden zo snel mogelijk uit de wet moeten worden verwijderd. ${ }^{60} \mathrm{Wij}$ zullen nooit alle voorwaarden die hebben bijgedragen tot een bepaalde gebeurtenis tot in detail kunnen doorgronden. Zo een zekerheid bestaat niet, wel waarschijnlijkheid. ${ }^{6 \mathrm{r}}$ Het gaat erom of bepaald gedrag het intreden van een gevolg in het algemeen bevordert. Niet iedere condicio sine qua non

$58 \quad$ HR 7 februari 1938, NJ I938, 918.

59 Prof. Mr. J.M. van Bemmelen/Prof. Mr. W.F.C. van Hattum, Hand- en Leerboek van het Nederlandse Strafrecht, Deel I, Algemene Leerstukken, Arnhem I953, nr. I20.

6o Van Bemmelen/Van Hattum, nr. I23.

6I Van Bemmelen/Van Hattum, nr. I26 
is ook adequaat causaal. Onverwacht tussenkomende factoren kunnen de adequatiecausaliteit verbreken. Er kan verschillend worden gedacht over de details die bij het waarschijnlijkheidsoordeel worden betrokken. ${ }^{62} \mathrm{Bij}$ de door het gevolg gekwalificeerde geweldsdelicten kunnen lichamelijke bijzonderheden van het slachtoffer ten laste komen van de dader omdat nu eenmaal het gebruik van geweld naar ervaringsregels gemakkelijk anders kan uitvallen dan aan de dader voor ogen stond..$^{6}$ Van Hattum stelt zich op het standpunt dat ook nalaten oorzaak kan zijn wanneer de dader tot handelen verplicht was. ${ }^{64}$ Ook Pompe neemt de condicio sine qua non als uitgangspunt. ${ }^{65}$ Maar om oorzaak te heten is nodig dat die voorwaarde de strekking heeft het gevolg te doen intreden. De strekking hangt af van de waarschijnlijkheid van het gevolg, gegeven alle op het moment van handelen bestaande omstandigheden. Ook de verborgen lichamelijke kwetsbaarheden van het slachtoffer moeten bij het waarschijnlijkheidsoordeel worden betrokken alsof zij bekend waren. ${ }^{66}$ Nalaten kan eveneens zo een strekking hebben. ${ }^{67}$ Langemeijer stelt de vraag aan de orde welk causaal verband voor aansprakelijkheid relevant is. Niet iedere condicio sine qua non maakt immers aansprakelijk. Wat voor de ene delictsgroep relevant is, hoeft dat niet voor de andere te zijn. ${ }^{68} \mathrm{Bij}$ de materieel omschreven opzetdelicten is de vorm van het opzet relevant voor de aansprakelijkheid voor gevolgen. Hoe sterker het opzet, des te minder eisen gelden voor het relevante causaal verband. Bij de door het gevolg gekwalificeerde delicten heeft de wetgever het oog op gevolgen die al voorzienbaar zijn. Niet kenbare zwakke plekken van het slachtoffer maken het causaal verband nog niet irrelevant. ${ }^{69}$ Volgens Langemeijer kan ook nalaten relevante oorzaak zijn, waarbij de dringendheid van de plicht tot handelen gewicht in de schaal legt. ${ }^{70}$

\section{$5 \quad$ De redelijke toerekening}

\section{I Kritiek op de adequatieleer}

Gedurende bijna een halve eeuw heeft de redelijke voorzienbaarheid de causaliteitsvraag beheerst. De kritiek op deze invulling had met name betrekking op de elasticiteit ervan. Hoe algemener de voorzienbaarheid werd ingevuld des te gemakkelijker ook causaal verband werd aangenomen. Voorzienbaarheid is een flexibel begrip dat kan worden aangepast al naargelang de uitkomst die men redelijk acht. ${ }^{71}$

\footnotetext{
62 Van Bemmelen/Van Hattum, nr. I29.

63 Van Bemmelen/Van Hattum, nr. I34.

64 Van Bemmelen/Van Hattum, nr. I36.

65 Mr. W.P.J. Pompe, Handboek van het Nederlandse Strafrecht, Zwolle I959, p. 9I.

66 Pompe, Handboek, p. 93.

67 Pompe, Handboek, p. 97.

68 Het Wetboek van Strafrecht verklaard door Mr. J.J. Noyon, vijfde druk bewerkt door Prof. Mr. G.E. Langemeijer, Eerste Deel. Inleiding. Boek I, Arnhem I947, p. 46.

69 Langemeijer, p. 49.

$70 \quad$ Langemeijer, p. 5I/52.

7I Aldus reeds S. van Brakel, Opmerkingen over causaliteit III, W. I2702.
} 
Van Eck had reeds alle causaliteitstheorieën aan een onderzoek onderworpen en geconcludeerd dat geen ervan deugde, zij het dat de uitkomsten van een aantal ervan wel redelijk waren. De vraag naar het causaal verband wordt volgens hem in het strafrecht gegenereerd door een te letterlijke uitleg van de delictsomschrijving.72 De verschillende causaliteitsleren schieten als causaliteitstheorieën tekort, maar zijn volgens hem wel van waarde in het kader van een theorie over gevolgsaansprakelijkheid. ${ }^{73}$

\subsection{De civielrechtelijke ommezwaai}

\section{Rechtspraak omarmt redelijke toerekening}

Deze kritiek werd ook door verschillende civilisten verwoord. ${ }^{74}$ In HR 20 maart I970, NJ I970, 25I m.nt. Scholten ging de Hoge Raad, zij het enigszins besmuikt, in civiele zaken overstag. Een tankwagen met olie was in een waterwingebied tegen een boom gebotst en de instantie die voor het waterwingebied verantwoordelijk was, had maatregelen genomen om schade aan de bodem zoveel mogelijk te voorkomen. Die instantie vorderde de kosten van deze maatregelen van de vervoerder. De rechtbank wees de eis af omdat niet kenbaar was dat de plaats van het ongeval deel uitmaakte van een waterwingebied. Het hof oordeelde evenwel dat in de bodem in Nederland water wordt opgeslagen en dat schade aan die wateropslagplaats als gevolg van verspreiding van olie in de bodem redelijkerwijs is te verwachten. In cassatie overwoog de Hoge Raad dat bij een massaal uitstromen van olie over de grond schade aan de waterwinning niet een zo uitzonderlijke vorm van schade als gevolg van een ongeluk met een met olie geladen tankauto is, noch in een zo ver verwijderd verband daarmee staat, dat die schade in redelijkheid niet ten laste mag worden gebracht van degene die krachtens de wet aansprakelijk is voor de gevolgen van het ongeluk. Door gebruik te maken van woorden als 'uitzonderlijk' is de weg naar de adequatiecriteria niet afgesneden. In die leren wordt immers onderzocht of een bepaald gevolg redelijkerwijs, in het algemeen te verwachten en niet uitzonderlijk is. Ook een toespeling op de causa proxima is aan te wijzen. Maar sindsdien is de redelijke toerekening in de rechtspraak van de civiele kamer van de Hoge Raad het heersende uitgangspunt..$^{75}$

72 D. van Eck, Causaliteit en aansprakelijkheid voor gevolgen in het strafrecht, Deel I, Nijmegen I947, p. 30 e.v., 38, 8I, p. I34.

73 Van Eck, Causaliteit en aansprakelijkheid, p. 78 e.v.

74 H.K. Köster, Causaliteit en voorzienbaarheid, Zwolle r963; A.R. Bloembergen, Schadevergoeding bij onrechtmatige daad, Deventer 1965; J. van Schellen, Juridische causaliteit, Deventer I972.

75 Zie bijv. HR 2I maart 1975, NJ 1975, 372 m.nt. G.J. Scholten: ongeval doordat bestuurder geen voorrang heeft verleend. Het slachtoffer overlijdt kort na het ongeval aan een hartaanval, veroorzaakt door emotie, ontstaan door de aanrijding. Bestuurder die zo'n fout maakt, is doorgaans aansprakelijk, tenzij het overlijden redelijkerwijs niet meer als gevolg van de aanrijding kan worden toegerekend. 
De invoering van het nieuw BW heeft de aanvaarding van de redelijke toerekening bevorderd. In het BW is thans in de afdeling over de wettelijke verplichtingen tot schadevergoeding in artikel 6:98 bepaald dat voor vergoeding slechts in aanmerking komt schade die in zodanig verband staat met de gebeurtenis waarop de aansprakelijkheid van de schuldenaar berust dat zij hem, mede gezien de aard van de aansprakelijkheid van de schade, als gevolg van deze gebeurtenis kan worden toegerekend. Dit artikel is het gevolg van een switch in gedachten over de gevolgsaansprakelijkheid. In het op I5 april I97I door de Commissie van Justitie van de Tweede Kamer vastgestelde Voorlopig Verslag tot vaststelling van Boek 6 van het nieuwe $\mathrm{BW}^{7}$ hechtte de Commissie nog aan het voorzienbaarheidsvereiste zoals dat in het ontwerp was opgenomen. Nieuwe publicaties van Köster en Bloembergen brachten de Commissie niet tot andere gedachten. In het Voorlopig Verslag, vastgesteld op I5 september $1975,{ }^{77}$ twijfelde de Commissie echter aan de stelligheid waarmee zij eerder aan het voorzienbaarheidsvereiste had vastgehouden en stelde in haar onzekerheid nadere vragen aan de Minister. In de Memorie van Antwoord ${ }^{7}$ herhaalde de Minister dat het oorspronkelijke ontwerp bestond uit een door een commissie van drie wijzen opgesteld voorontwerp voor Boek 6 , dat ongewijzigd aan de volksvertegenwoordiging is aangeboden omdat het overlijden van een van de drie opstellers het ondoenlijk maakte om binnen gepaste tijd nog alle reacties op het voorontwerp te verwerken. Maar in het gewijzigd ontwerp zijn alle ontwikkelingen verwerkt en is aangesloten bij de richting die inmiddels blijkens de rechtspraak ook de heersende leer is geworden en die het voorzienbaarheidsvereiste als enig causaliteitscriterium achter zich heeft gelaten. ${ }^{79}$

\subsection{Strafrechtelijke koerswending; redelijke toerekening}

Het komt mij voor dat deze ommezwaai in de rechtspraak van de civiele kamer en de totstandkoming van het nieuw BW ook hun invloed hebben gehad op de rechtspraak van de strafkamer van de Hoge Raad. In de zeventiger jaren heeft ook de strafkamer de redelijke toerekening omarmd. ${ }^{80}$ Het wekt geen verbazing dat deze rechtspraak tot stand kwam in zaken waarin verdachte het causaal verband tussen zijn gedrag en het gevolg betwistte en op andere omstandigheden wees die tot het gevolg hebben bijgedragen.

76 Kamerstukken II I970/7I, 7729, nr. 4, p. I9.

77 Kamerstukken II I974/75, 7729, nr. 5, p. 5.

78 Kamerstukken II $1975 / 76,7729$, nrs. 6-7, p. I.

79 Kamerstukken II r975/76, 7729, nrs. 6-7, p. 9I.

8o Maar het moet gezegd worden dat niet de Hoge Raad maar de Rechtbank Assen een der eerste zoniet de eerste was die de nieuwe richting volgde in een vonnis van 30 juni I978, NJ I978, 556 m.nt. Van Veen. 
In HR I2 september 1978, NJ I979, 6o m.nt. Van Veen (longembolie) sprak de Hoge Raad zich voor het eerst uit en wel meteen in een zaak waarin medische complicaties waren opgetreden na een ongeval. Verdachte was hoogst onvoorzichtig een kruising opgereden en was tegen een andere auto gebotst. Een inzittende van die andere auto is overleden. Bij sectie bleek dat de opgelopen verwondingen weliswaar ernstig waren maar niet noodzakelijkerwijs tot de dood behoefden te leiden. Het slachtoffer is overleden aan een dodelijke longembolie, het gevolg van een complicatie van de door de letsels noodzakelijk geworden bedrust. In cassatie betwistte verdachte het causaal verband tussen de dood van het slachtoffer en de botsing. De Hoge Raad verwierp deze klacht omdat het optreden van een lethale longembolie na door een botsing bekomen letsels zoals hier opgelopen niet van zodanige aard is dat het overlijden van het slachtoffer redelijkerwijs niet meer als gevolg van de botsing aan de dader zou kunnen worden toegerekend. ${ }^{8}{ }^{\mathrm{I}}$ Nadien zijn nog meer gevallen van medische complicaties door de strafkamer met behulp van de redelijke toerekening afgehandeld. Bijvoorbeeld het zogenoemde aortaperforatiearrest (HR 23 december I980, NJ I98I, 534 m.nt. G.E. Mulder), waarin verdachte is veroordeeld voor zware mishandeling de dood ten gevolge hebbend. Bij sectie was gebleken dat twee minieme steekwonden in de aorta bij een daarop volgende operatie niet zijn opgemerkt. De Hoge Raad overwoog dat voor de vaststelling van het causaal verband beslissend is of de dood redelijkerwijs als gevolg van de messteek in de maag en de aorta van het slachtoffer aan verdachte kan worden toegerekend. Aan die toerekening hoeft niet in de weg te staan het geopperde verzuim van de behandelend arts. $^{82}$ In zijn noot toonde Mulder zich kritisch. Volgens hem dreigt zo een cirkelredenering en een vermenging van subjectieve en objectieve delictsbestanddelen.

8I Dat wil niet zeggen dat andere formuleringen van het causaal verband volledig in de ban zijn gedaan. In HR 20 november I990, NJ I99I, 302 bijv. had het hof veroordeeld voor mishandeling de dood ten gevolge hebbend. Het hof had aangenomen dat de dood van het slachtoffer een onmiddellijk en rechtstreeks gevolg was van het slaan door verdachte en de val van het slachtoffer. Het hof greep dus terug naar de woorden van artikel $1284 \mathrm{BW}$. In cassatie volstond de HR met de overweging dat het hof het causaal verband uit de gebezigde bewijsmiddelen heeft kunnen afleiden.

82 Zie ook HR 3 maart I998, nr. I06.953 (niet gepubliceerd). Bij een voetbalwedstrijd ontstond een vechtpartij waarbij een toeschouwer, die probeerde de zaak te sussen, werd mishandeld. De dag daarna stelde de huisarts als diagnose dat het slachtoffer ribkneuzingen heeft opgelopen. Zestien dagen na de mishandeling overleed het slachtoffer in het ziekenhuis. Bij de sectie werden ribbreuken en een scheur in de lichaamsslagader gevonden, hetgeen tot de dood heeft geleid. Verdachte werd veroordeeld voor het medeplegen van zware mishandeling de dood ten gevolge hebbend en ging in cassatie. De HR oordeelde dat de beslissing van het hof dat het door verdachte en zijn mededaders met grote kracht tegen het lichaam en het hoofd van het slachtoffer trappen en slaan de scheur in de lichaamsslagader bij het slachtoffer heeft veroorzaakt, niet onbegrijpelijk is en dat de dood van het slachtoffer redelijkerwijs als gevolg van die mishandeling aan verdachte en zijn mededaders kan worden toegerekend. Het tijdsverloop van I 6 dagen tussen mishandeling en overlijden doet er niet toe. Klaarblijkelijk is de gebleken omstandigheid dat de huisarts een onjuiste diagnose heeft gesteld niet van voldoende relevantie om aan redelijk toerekening in de weg te staan. Zie ook nog HR 30 maart 2004, ECLI:NL:HR:2004:AO323I; het uitblijven van de vereiste medische hulp na het feit kan aan het causaal verband niet afdoen nu 
Ik noem voorts $\mathrm{HR} 7$ mei 1985 , NJ I985, 82I m.nt. 't Hart, waarin verdachte veroordeeld was voor doodslag. Hij had een ander herhaalde malen met een mes gestoken in diens hoofd en lichaam. Zeven dagen nadien overleed het slachtoffer omdat door inwendige verwondingen de bloedtoevoer naar de hersenen tekort schoot. In cassatie werd de vraag opgeworpen of aan het aannemen van causaal verband in de weg stond dat het slachtoffer bij adequaat medisch ingrijpen nog volledig had kunnen herstellen. De Hoge Raad verwierp deze klacht, omdat - ook als die door het middel opgeworpen mogelijkheid had bestaan - dit er niet aan in de weg stond dat de dood van het slachtoffer als het gevolg van het handelen van de verdachte, wiens opzet op de dood van de ander was gericht, aan hem wordt toegerekend. Dat medische zorg nodig was, is te wijten geweest aan het wangedrag van verdachte en dat er sprake was van ontbrekende of tekortschietende medische zorg door anderen ontheft de verdachte niet van zijn aansprakelijkheid voor zijn handelingen waarmee hij de dood van de ander heeft nagestreefd..$^{83}$

Het longemboliearrest leert mijns inziens dat op zichzelf de gedragingen van verdachte nog niet noodzakelijkerwijs tot het door de wet genoemde gevolg behoeven te leiden. Daaropvolgend medisch falen doorbreekt de causale keten doorgaans niet. Wanneer een verdachte met het opzet op levensberoving inderdaad verwondingen toebrengt die op zichzelf niet dodelijk zijn, maar die door onoordeelkundige medische behandeling wel tot de dood van het slachtoffer leiden, zal die dood aan de dader als doodslag kunnen worden toegerekend. Voor culpoze delicten geldt een vergelijkbare gedachtegang. Als door grove onvoorzichtigheid een verkeersslachtoffer in het ziekenhuis belandt en vervolgens bezwijkt aan onnodige complicaties zal verdachte veroordeeld kunnen worden voor dood door schuld. Voor door het gevolg gekwalificeerde mishandelingen ligt de situatie vergelijkbaar. Als de gedragingen van verdachte zelf al levensbedreigend zijn, ligt de situatie natuurlijk eenvoudiger dan wanneer niet, te laat of onoordeelkundig daarop wordt gereageerd.

\section{Redelijke toerekening en lichamelijke disposities van het slachtoffer}

Naast deze gevallen van medische complicaties heeft de Hoge Raad ook zaken beslist waarin een lichamelijke kwetsbaarheid van het slachtoffer wellicht een rol speelde. Met name gaat het dan om hartfalen van kwetsbare slachtoffers die zijn geconfronteerd met hevige emoties, opgewekt door gedragingen van verdachte. Wanneer bij sectie blijkt dat het slachtoffer bijvoorbeeld leed aan enigerlei vorm van

het door verdachte toegebrachte letsel kennelijk zo ernstig was dat een medische ingreep noodzakelijk was om te voorkomen dat het slachtoffer zou komen te overlijden.

83 In HR I6 maart I999, nr. IIo.987 (niet gepubliceerd) werd opgekomen tegen de veroordeling voor doodslag omdat het oorzakelijk verband tussen de gedragingen van verdachte en de dood van het slachtoffer ontoereikend was aangetoond nu het overlijden van slachtoffer ook kon worden verklaard door complicaties bij het opvolgend medisch handelen. De Hoge Raad verwierp deze klacht omdat het hof tot uitdrukking heeft gebracht dat verdachte de omstandigheden in het leven heeft geroepen die tot de dood van het slachtoffer hebben geleid en dat de medische complicaties niet een zodanige invloed hebben gehad op de keten der gebeurtenissen dat de dood van het slachtoffer redelijkerwijs niet meer als gevolg van het handelen van de verdachte aan hem zou kunnen worden toegerekend. 
hartzwakte ligt het voor de hand dat de verdediging die dispositie als oorzaak van het overlijden aanwijst.

In HR I2 november I985, NJ I986, 782 m.nt. ALM was het bejaard slachtoffer van een overval, dat leed aan ziekelijke afwijkingen van hart- en bloedvaten, aan hartfalen overleden. Rechtbank en hof hadden verwezen naar het sectierapport waarin de patholoog had opgemerkt dat een overlijden als waarvan hier sprake was, veroorzaakt kan worden door emotionering. De feitenrechters hadden aangenomen dat een dergelijke emotionering heeft plaatsgevonden, veroorzaakt door het op het slachtoffer uitgeoefende geweld zodat haar dood, mede gelet op het van algemene bekendheid zijnde feit dat hevige emoties bij bejaarden dikwijls fatale gevolgen hebben, redelijkerwijs aan verdachten kon worden toegerekend. De Hoge Raad overwoog dat rechtbank en hof met juistheid hebben geoordeeld dat het een feit van algemene bekendheid is dat hevige emoties bij bejaarden dikwijls fatale gevolgen hebben. Het oordeel dat de dood van het slachtoffer redelijkerwijs aan verdachten kon worden toegerekend was niet onbegrijpelijk..$^{84}$

Voorts verwijs ik naar HR 20 september 2005, NJ 2006, 86. Verdachte had een vrouw van 76 jaar in haar woning overvallen. Het slachtoffer overleed. Haar medische toestand was verre van optimaal. De patholoog rapporteerde dat bij sectie geen anatomische doodsoorzaak gevonden is. Er kan een hartritmestoornis zijn opgetreden, maar dat kon niet bij sectie worden vastgesteld. Een fatale hartritmestoornis kan optreden in situaties van hevige stress, met name als - zoals hier - het hart al groot is en de kransslagaders vernauwd zijn. De Hoge Raad meende dat het hof de tijdens of kort na de overval ingetreden dood van het slachtoffer in redelijkheid aan verdachte en zijn mededader heeft kunnen toerekenen. De Hoge Raad achtte het een feit van algemene bekendheid dat het geconfronteerd worden met een gewelddadige overval in de eigen woning, zeker bij een slachtoffer op leeftijd, hevige emoties oproept, die, zoals ook een deskundige had verklaard, tot de dood kunnen leiden.

In deze gevallen is de bron van de complicaties niet eerst opgetreden na het handelen van verdachte, bijvoorbeeld door ontoereikend medisch ingrijpen, maar al daarvóór gegeven in de persoon van het slachtoffer. De verborgen kwetsbaarheid van het slachtoffer komt voor rekening van de dader. Daardoor hoeft niet meer exact te worden vastgesteld welke invloed zij op de afloop heeft gehad. Deze rechtspraak beperkt zich tot overvallen waarbij de dood van het slachtoffer een kwalificerend gevolg is. Opzet of culpa aan dat gevolg hoeft niet bewezen te worden. Ook voor andere door het gevolg gekwalificeerde delicten lijkt mij dit op te gaan. Zo zal een mishandeling de dood ten gevolge hebben ook als daarin een lichamelijke dispositie van het slachtoffer een rol heeft gespeeld. Als verdachte opzet heeft gehad op dat gevolg is er nog minder reden om hem dat gevolg niet toe te rekenen. Het handelen van verdachte heeft dan gewoonlijk de strekking al om zo een gevolg teweeg te brengen. Voor de culpoze delicten lijkt mij toerekening van het gevolg in zo'n geval ook

84 Zie ook HR 20 maart 200I, NJ 200I, 340 waarin verdachten een bejaarde man met geweld in zijn woning hadden overvallen. Het slachtoffer overleed korte tijd nadien. De Hoge Raad overwoog dat het hof heeft vastgesteld dat de hartritmestoornissen die tot de dood hebben geleid zijn veroorzaakt door de emoties die door verdachten zijn opgewekt. Terecht heeft het hof overwogen dat de omstandigheid dat het slachtoffer reeds hartklachten had daaraan niet afdoet. 
voor de hand te liggen wanneer het handelen de strekking heeft zo een gevolg te doen ontstaan. Wanneer het handelen deze strekking niet heeft, zal moeten worden uitgeweken naar de door het gevolg gekwalificeerde culpoze delicten als men dit gevolg op rekening van verdachte wil schrijven. Ook daar is wel een soort strekkingsverband nodig, maar dat lijkt mij elastischer dan bij de doleuze of culpoze delicten. Te denken is aan de culpoze misdrijven waardoor de algemene veiligheid van personen in gevaar wordt gebracht.

\section{Redelijke toerekening en fouten/beslissingen van het slachtoffer}

Niet alleen lichamelijke gebreken van het slachtoffer worden als belemmering aangevoerd om een gevolg niet aan verdachte te behoeven toe te rekenen, maar ook fouten of beslissingen van het slachtoffer zelf worden wel als zodanig gepresenteerd.

Als een bestuurder van een auto met behoorlijke snelheid achterop een voor hem staande auto aanrijdt, zodat deze auto tegen een lichtmast botst en een inzittende door de voorruit uit deze auto wordt geslingerd en zwaar lichamelijk letsel oploopt, is dat letsel redelijkerwijs als gevolg van de door verdachte veroorzaakte aanrijding aan hem toe te rekenen. Daaraan doet niet af dat het slachtoffer geen veiligheidsgordel droeg en dat het letsel volgens de verdediging hoogstwaarschijnlijk voorkomen had kunnen worden indien de autogordel wel was gebruikt. ${ }^{85}$ In de rechtspraak van de Hoge Raad is vooral HR 25 juni 1996, NJ 1997, 563 m.nt. 't Hart (AA 1997, p. 49 m.nt. de Hullu) bekend geworden. Verdachte had op zijn vriendin geschoten die als gevolg daarvan een hoge dwarslaesie bekwam. In het ziekenhuis moest zij kunstmatig worden beademd. Als verwikkeling trad een longontsteking op waaraan het slachtoffer niet behandeld wilde worden, hoewel dat medisch gezien wel mogelijk was. Vijf dagen na het schot overleed zij aan de longontsteking. Het hof had de longontsteking aangemerkt als een rechtstreeks gevolg van het schot. Dat het slachtoffer zelf had besloten om een behandeling niet meer toe te staan doet daaraan niet af, aangezien die behandeling, als die al tot enige levensverlenging zou hebben geleid, geen menswaardig bestaan had opgeleverd. Daarom staat de beslissing van het slachtoffer niet aan toerekening van de dood aan verdachte in de weg. Verdachte voerde in cassatie aan dat het causaal verband door de zelfstandige beslissing van het slachtoffer wel degelijk was doorbroken. Volgens de Hoge Raad had het hof tot uitdrukking gebracht dat verdachte de omstandigheden in het leven heeft geroepen die het slachtoffer ertoe hebben gebracht die beslissing te nemen en dat die beslissing in de keten der gebeurtenissen niet een zodanige invloed heeft gehad dat de dood van slachtoffer redelijkerwijs niet meer aan verdachte zou kunnen worden toegerekend. Dat oordeel is niet onjuist en niet onbegrijpelijk, in aanmerking genomen het buitengewoon ernstig letsel dat het slachtoffer door toedoen van verdachte had opgelopen. ${ }^{86}$

85 HR II december 200I, NJ 2002, 62.

86 Zie voorts HR I6 maart I999, NJ I999, 387, waarin verdachte was veroordeeld voor het veroorzaken van zwaar lichamelijk letsel door schuld. Verdachte had het slachtoffer ernstig bedreigd, waarna het slachtoffer, op de vlucht, via een dak naar de grond sprong en ernstig letsel opliep. Het hof heeft volgens de HR tot uitdrukking gebracht dat verdachte de omstandigheden in het 
Hoe ver die redelijke toerekening kan gaan blijkt wel in Gerechtshof 's-Gravenhage 7 mei 2002, NJ 2002, 55I. Verdachte had op 7 juni 1999 het slachtoffer met het doel hem om het leven te brengen vele malen met een honkbalknuppel en een vuurwapen op het hoofd geslagen. Het slachtoffer is met ernstig hoofd- en hersenletsel in het ziekenhuis opgenomen en volgens het hof zou het letsel bij een iets later aangevangen medische behandeling reeds toen fataal zijn geweest. Het slachtoffer heeft gedurende maanden in het ziekenhuis verbleven en vervolgens nog lange tijd in een revalidatiekliniek. De revalidatiekliniek heeft hij in mei 2000 tegen het advies van zijn artsen in verlaten. Deskundigen hadden verklaard dat het slachtoffer niet meer zelfstandig kon functioneren. Zijn hersenen zijn door het geweld zodanig beschadigd geraakt dat hij geen ziekte-inzicht en zelfkritiek meer had. Tevens waren er ernstige lichamelijke klachten als gevolg van het letsel, hetgeen er uiteindelijk toe heeft geleid dat het slachtoffer op I4 oktober 2000 aan een longontsteking is overleden. Het hof oordeelde dat de dood van het slachtoffer redelijkerwijs aan het opzettelijk handelen van verdachte diende te worden toegerekend, niettegenstaande de mogelijkheid dat het slachtoffer ook vóór juni 1999 problemen met zijn gezondheid had en daar te weinig rekening mee hield en de mogelijkheid dat de kans op fatale complicaties kleiner zou zijn geweest als door hulpverleners anders met het slachtoffer was omgesprongen.

\section{$5 \cdot 4 \quad$ Literatuur}

De aanvaarding van de redelijke toerekening in het strafrecht is bekritiseerd, met name door Nieboer en Strijards. Zij wijzen op het belang van de voorzienbaarheid voor het strafrecht, onder meer voor de schuld en de preventie. Redelijke toerekening is onbegrensd en nietszeggend. ${ }^{87}$ Vellinga daarentegen juicht het nieuwe criterium toe. Bij de culpoze delicten hebben gedetailleerde veiligheidsvoorschriften de rol van de voorzienbaarheid teruggedrongen. Voorzienbaarheid kan zonder schuld, bijvoorbeeld bij het geoorloofde risico. De voorzienbaarheid is inmiddels zover opgerekt dat alle denkbare gevolgen ook redelijkerwijs te voorzien zijn. De Hoge Raad heeft door de aanvaarding van de redelijke toerekening ook andere criteria dan de voorzienbaarheid voor de causaliteit bruikbaar geacht. ${ }^{88}$ Remmelink schrijft dat de redelijke toerekening niet tot andere resultaten komt dan de redelijke voorzienbaarheid, maar erkent dat de redelijke toerekening gemakkelijker weg weet met bij voorbeeld onvoorziene medische fouten. ${ }^{89}$ De Hullu wijdt uitgebreide beschouwingen aan de verschillende causaliteitsleren en omarmt uiteindelijk de redelijke toerekening omdat die recht kan doen aan alle omstandigheden van het geval en uitdrukt

leven heeft geroepen die het slachtoffer in een dwangpositie hebben gebracht en op deze wijze hebben doen wegvluchten. De HR oordeelde overigens in antwoord op een van de cassatieklachten dat deze gang van zaken voor verdachte redelijkerwijs voorzienbaar moet zijn geweest en sprak niet van redelijke toerekening.

87 W. Nieboer en G.A.M. Strijards, Voorzienbaarheid - een juridische hulpconstructie?, DD I979, p. 440 e.v.

88 W.H. Vellinga, Voorzienbaarheid en redelijke toerekening, DD I979, p. IIo e.v.

89 HSR, p. I86. 
dat het gaat om een normatief getoonzet vraagstuk, zonder dat benaderingen die in het verleden hun waarde hebben bewezen geheel naar de achtergrond verdwijnen..$^{\circ}$

\section{Complicaties met de condicio sine qua non}

\section{I Onzekerheid over het condicio sine qua non-verband}

Maar wat als het condicio sine qua non-verband niet 100\% vaststaat? Kan, als andere factoren ook zonder het handelen van verdachte tot het gevolg kunnen hebben geleid, het gevolg nog wel redelijkerwijs aan verdachte worden toegerekend?

In de Nederlandse rechtspraak zijn daarover inmiddels enige uitspraken verschenen die mijns inziens aantonen dat het bewijs van een 100\% zekerheid niet nodig is. In HR I3 juni 2006, NJ 2007, 48 m.nt. Buruma had verdachte het slachtoffer op 27 mei 2004 met een mes in de rug, ter hoogte van de long, gestoken. Het slachtoffer is op 28 mei 2004 opgenomen in het ziekenhuis en heeft dat ziekenhuis op 2 juni 2004 in stabiele toestand verlaten. Op 8 juni 2004 is hij weer opgenomen in een ziekenhuis waar hij op 23 juni 2004 overleed. Het overlijden is door de patholoog verklaard door een algeheel orgaanfalen na een ernstige bloedvergiftiging. Een relatie tussen de steekletsels en de infectie is niet met zekerheid te leggen. In hoger beroep heeft een deskundige verklaard dat het in theorie mogelijk is dat het slachtoffer de infectie heeft opgelopen in de periode tussen het eerste ontslag uit het ziekenhuis en de tweede opname. Het hof maakte uit de verklaringen van deskundigen op dat de mogelijkheid is blijven bestaan, hoe klein en onwaarschijnlijk ook, dat het slachtoffer de infectie anders dan door de messteek heeft opgelopen. Daarom achtte het hof zich niet in staat het causaal verband tussen de gedraging van verdachte en de dood van het slachtoffer met zekerheid vast te stellen en kan volgens het hof het overlijden van het slachtoffer redelijkerwijs niet als gevolg van de messteek aan verdachte worden toegerekend. Verdachte werd daarom vrijgesproken van doodslag, maar veroordeeld voor poging tot doodslag. In cassatie overwoog de Hoge Raad dat het hof terecht heeft geoordeeld dat de vaststelling van het causaal verband dient te geschieden aan de hand van de maatstaf of de dood redelijkerwijs aan verdachte kan worden toegerekend. Dat een infectie de directe doodsoorzaak is geweest sluit zo een verband tussen de messteek en de infectie niet uit. Het hof heeft geen causaal verband aanwezig geacht vanwege de mogelijkheid 'hoe klein en onwaarschijnlijk ook' dat het slachtoffer de infectie niet door de messteek heeft opgelopen. Maar een hoogst onwaarschijnlijke mogelijkheid van een alternatieve gang van zaken staat aan een bewezenverklaring van het causaal verband niet in de weg. In dezelfde zin besliste de Hoge Raad in HR 28 november 2006, NJ 2007, 49 m.nt. Buruma. In een café was tegen het slachtoffer geweld gebruikt en het slachtoffer had ernstig hoofd- en hersenletsel opgelopen. Het hof had vrijgesproken van het strafverzwarend gevolg omdat het niet geheel uitgesloten achtte dat het lichamelijk 
letsel mede is veroorzaakt door de wijze waarop het slachtoffer door derden uit het café naar buiten is gebracht, 'te weten door, terwijl hij op zijn rug op de grond lag, aan zijn armen en benen te trekken en hem via de van traptreden voorziene voordeur over de vloer naar buiten te slepen'. Ook hier had het hof volgens de Hoge Raad de te gebruiken maatstaf miskend door aan te nemen dat aan een bewezenverklaring van het causaal verband in de weg staat dat niet geheel kan worden uitgesloten dat latere handelingen van derden mede hebben geleid tot dat letsel.

Deze beide arresten passen wel bij de aanwijzing die de Hoge Raad in HR I6 maart 20I0, NJ 20I0, 314 m.nt. Buruma heeft gegeven voor de wijze waarop de feitenrechter kan omgaan met een verweer dat de tenlastelegging bestrijdt met een alternatieve lezing van de gebeurtenissen. Als de rechter die alternatieve lezing niet aanvaardt en tot een bewezenverklaring komt, zal hij die moeten weerleggen. Dat kan geschieden door contraire bewijsmiddelen op te nemen of door in een bewijsoverweging te wijzen op feiten en omstandigheden die de alternatieve lezing ontkrachten. Soms kan de rechter de weerlegging baseren op zijn oordeel dat de alternatieve lezing niet aannemelijk is geworden of de lezing van verdachte ongeloofwaardig is. En tot slot kunnen zich gevallen voordoen waarin de lezing van verdachte zo onwaarschijnlijk is dat zij geen uitdrukkelijke weerlegging behoeft. Honderd procent zekerheid dat er geen sprake was van een alternatief scenario behoeft dus, in weerwil van wat het hof in deze beide arresten tot uitgangspunt lijkt te hebben genomen, niet te bestaan.

Ik bespeur wel een verschil tussen beide casus. In de infectiezaak ging het om de - zeer geringe - mogelijkheid dat het oplopen van de infectie helemaal niets te doen had met het steken door verdachte. De infectie kan heel misschien zijn opgetreden zonder dat er enig verband met het steken is geweest. In de tweede zaak zou als verdachte geen geweld had gebruikt het slachtoffer niet op deze wijze uit het café verwijderd zijn. In het eerste geval is er duidelijker sprake van een probleem van zogenoemde Doppelkausalität dan in het tweede.

Het eerste geval lijkt daarom ook meer op de geruchtmakende Groninger hivzaak dan het tweede. In die zaak (HR 27 maart 20I2, NJ 2012, 30I m.nt. Keijzer) werden verdachten ervan beschuldigd dat zij anderen zwaar lichamelijk letsel, te weten een hiv-besmetting, hebben toegebracht door slachtoffers met hiv-besmet bloed te injecteren. Verdachten organiseerden seksbijeenkomsten voor homoseksuele mannen. Een van de verdachten was met hiv besmet. Samen bespraken verdachten de mogelijkheid om gasten te drogeren en hen ook te besmetten, om zo onbezorgd en zonder terughoudendheid seks met elkaar te kunnen hebben. Verdachten hebben dit plan ook uitgevoerd. Uiteindelijk bleken vier van hun gasten ook met het hiv-virus besmet te zijn. De verdediging betoogde dat de hiv-besmetting ook door onveilige seks op die bijeenkomsten of elders kon zijn opgelopen. Het hof stelde de vraag of de hiv-besmetting redelijkerwijs als gevolg van het handelen van verdachten aan hen kan worden toegerekend. Volgens het hof was zo'n toerekening redelijk als hun gedragingen naar haar aard geschikt waren om een hiv-besmetting teweeg te brengen of het gevaar daarvoor in relevante mate te vergroten. Dat niet is uitgesloten dat tussenkomende handelingen van derden mede hebben geleid tot het ingetreden gevolg staat aan die toerekening niet in de weg. Op grond van de conclusies van een deskundige nam het hof aan dat de acties van verdachten naar hun aard (uitermate) geschikt waren om een hiv-besmetting teweeg te brengen of 
het gevaar daarvoor significant te vergroten. Ook hadden deskundigen zich uitgelaten over de fylogenetische aspecten van de besmetting. Transmissie tussen de slachtoffers en de besmette verdachte is wel aan te nemen, maar de richting waarin deze heeft plaatsgevonden was niet zeker. Het hof wees er nadrukkelijk op dat het opzet van verdachten op besmetting van de anderen was gericht. Dat de slachtoffers door onbeschermd seksueel verkeer in plaats van door de injecties besmet zijn geraakt is weliswaar niet ondenkbaar, maar de kans op die mogelijkheid is van een geheel andere orde. Het hof wees in dit verband op de verklaring van een van de deskundigen. De mogelijkheid van een alternatieve gang van zaken zoals door de verdediging voorgesteld behoeft daarom volgens het hof aan redelijke toerekening aan verdachten niet in de weg te staan. De Hoge Raad herhaalde dat de beantwoording van de vraag of causaal verband bestaat tussen de gedragingen van verdachten en de besmetting moet geschieden aan de hand van de maatstaf of de besmetting redelijkerwijs als gevolg van het inspuiten/injecteren van het besmette bloed aan verdachten kan worden toegerekend. Hij overwoog vervolgens dat doorgaans niet aan twijfel onderhevig is dat de gedraging van verdachte een noodzakelijke factor is geweest voor het ingetreden gevolg en dus in een condicio sine qua non-verband daarmee staat, welk verband in beginsel als ondergrens van het causaal verband fungeert; maar het gaat vooral om de vraag of het gevolg redelijkerwijs kan worden toegerekend. In uitzonderlijke gevallen, zoals het onderhavige, kan dat condicio sine qua non-verband niet zonder meer worden vastgesteld. Niet kan worden uitgesloten dat de hiv-besmetting in de onderhavige zaak alleen door derden is veroorzaakt. Maar zo'n onzekerheid hoeft niet steeds aan een redelijk toerekening in de weg te staan. De Hoge Raad vervolgt dan:

\begin{abstract}
'2.4.4. Het bovenstaande komt erop neer dat in gevallen als de onderhavige voor het redelijkerwijs toerekenen van het gevolg aan (een gedraging van) de verdachte ten minste is vereist dat wordt vastgesteld dat dit gedrag een onmisbare schakel kan hebben gevormd in de gebeurtenissen die tot het gevolg hebben geleid, alsmede dat ook aannemelijk is dat het gevolg met een aanzienlijke mate van waarschijnlijkheid door de gedraging van de verdachte is veroorzaakt. Of en wanneer sprake is van een dergelijke aanzienlijke mate van waarschijnlijkheid, zal afhangen van de concrete omstandigheden van het geval. Bij de beoordeling daarvan kan als hulpmiddel dienen of in de gegeven omstandigheden de gedraging van de verdachte naar haar aard geschikt is om dat gevolg teweeg te brengen en bovendien naar ervaringsregels van dien aard is dat zij het vermoeden wettigt dat deze heeft geleid tot het intreden van het gevolg (vgl. HR 20 september 2005, LJN AT8303, NJ 2006/86, rov. 3.5). Daarbij kan ook worden betrokken in hoeverre aannemelijk is geworden dat ten verwere gestelde andere, niet aan de gedraging van de verdachte gerelateerde oorzaken hoogstwaarschijnlijk niet tot dat gevolg hebben geleid.'
\end{abstract}

Het hof heeft - volgens de Hoge Raad niet onbegrijpelijk - geoordeeld dat de kans op een alternatieve toedracht aanzienlijk geringer is dan de kans op besmetting door inspuiting of injectie. Het is ervan uitgegaan dat die laatste kans zoveel groter is dan de kans dat de hiv-besmetting door gedragingen van derden is veroorzaakt, dat het vermoeden is gerechtvaardigd dat de besmetting van ieder van de slachtoffers met een redelijke mate van waarschijnlijkheid door de gedragingen van verdachte is 
teweeggebracht. Dat heeft het hof volgens de Hoge Raad kunnen aannemen. Maar dat is volgens de Hoge Raad nog niet voldoende:

'2.5.2. Het kennelijk oordeel van het Hof dat de gedragingen van de verdachte het bewezenverklaarde gevolg ook daadwerkelijk en ten aanzien van ieder van de aangevers hebben bewerkstelligd en, daarvan uitgaande, zijn oordeel dat dit gevolg ook redelijkerwijs aan diens gedragingen kan worden toegerekend, is echter niet toereikend gemotiveerd. Het Hof heeft immers niet vastgesteld dat hoogst onwaarschijnlijk is dat de hiv-besmetting van ieder van de aangevers het gevolg is van onbeschermde (anale) seks door iemand die met hiv is besmet. De omstandigheid dat de kans op hiv-besmetting door gedragingen van derden veel geringer is in verhouding tot de kans op besmetting door de gedragingen van de verdachte, houdt nog niet in dat die eerstbedoelde kans zo klein is, dat daaraan als hoogstonwaarschijnlijk kan worden voorbijgegaan.'

In zijn noot roept Keijzer op tot herbezinning op de rol van de condicio sine qua non in vragen naar causaliteit. De condicio sine qua non zou met name bij de mogelijkheid van parallelle medeveroorzaking tot een 'onthutsend resultaat' leiden.

Helemaal duidelijk vind ik dit arrest niet. Het ziet ernaar uit dat de Hoge Raad in overweging 2.4.4 eerst minimumvoorwaarden formuleert, te weten dat het gedrag een onmisbare schakel kan hebben gevormd naar het gevolg en dat aannemelijk is dat het gevolg met een aanzienlijke mate van waarschijnlijkheid door de gedraging van verdachte is veroorzaakt, en dan vervolgens aangeeft hoe die aanzienlijke mate van waarschijnlijkheid zou kunnen worden vastgesteld. Maar deze verwijzingen naar de aard van de gedraging zijn slechts illustratief, evenals de suggestie om daarbij te toetsen of tussenkomende oorzaken hoogstwaarschijnlijk niet tot het gevolg hebben geleid. Het hof had de conclusies van de deskundige overgenomen en geconcludeerd dat de gedragingen van verdachten telkens naar hun aard uitermate geschikt waren om een hiv-besmetting teweeg te brengen of het gevaar daarvoor significant te vergroten. Volgens de Hoge Raad heeft het hof deze slotsom uit de verklaring van de deskundige kunnen trekken en heeft het ook het vermoeden daarop kunnen baseren dat de gedragingen van verdachte hebben geleid tot het intreden van het gevolg. Dan komt de eis van de Hoge Raad dat het hof hier ook had moeten vaststellen dat de alternatieve route naar de hiv-besmetting hoogst onwaarschijnlijk is geweest wat onverwacht. In de structuur van de redenering die de Hoge Raad heeft neergelegd in overweging 2.4.4 is de vraag naar de kans dat andere oorzaken hoogstwaarschijnlijk niet tot het gevolg hebben geleid hoogstens een afgeleide hulpvraag. En deze wordt dan plotsklaps zodanig centraal gesteld dat zij de primaire vragen, te weten of het gedrag een onmisbare schakel kan hebben gevormd naar het gevolg en of aannemelijk is dat het gevolg met een aanzienlijke mate van waarschijnlijkheid door de gedragingen van verdachte is veroorzaakt, overschaduwt.

Ook vraag ik me af hoe het Groninger hiv-arrest zich verhoudt tot HR I6 maart 20I0, NJ 20I0, 314 m.nt. Buruma, waarin de Hoge Raad leerde dat een uitdrukkelijke weerlegging van een alternatief scenario niet nodig is als de lezing van verdachte erg onwaarschijnlijk is. Ik acht niet uitgesloten dat de Groninger hiv-zaak eerder een kwestie van bewijsrecht is dan een leerstellig causaliteitsarrest. 
Het arrest in de Groninger hiv-zaak is door de Hoge Raad gewezen op 27 maart 20I2. Ruim een maand eerder, op 3 februari 20I2, had het Gerechtshof Amsterdam een verdachte veroordeeld voor het medeplegen van diefstal met geweld en afpersing, de dood ten gevolge hebbende. Het hof heeft dus geen kennis kunnen nemen van het arrest van de Hoge Raad in de Groninger hiv-zaak.

Een juwelier en zijn vrouw werden in hun woning overvallen, waarbij de juwelier het leven liet. Volgens de patholoog had de overleden juwelier een voorbelast hart. Bij obductie bleek een klein hartinfarct met acuut opgetreden hartspierweefselversterf, maar ook nekletsel in het ruggenmerg en onder de hersenvliezen als gevolg van de inwerking van mechanisch geweld. Bij de overval was inderdaad geweld gebruikt. Beide letsels kunnen volgens de patholoog op zich en zeker in combinatie met elkaar het intreden van de dood verklaren. De beschadiging van het ruggenmerg kon volgens de deskundige zonder meer een neurogene schok tot gevolg hebben die het intreden van het overlijden al kan verklaren. Het hof had overwogen dat het de vraag is of de dood van de juwelier redelijkerwijs als gevolg van het op het slachtoffer uitgeoefende geweld kon worden toegerekend. Niet nodig is volgens het hof dat het overlijden uitsluitend het gevolg is geweest van het geweld en evenmin dat andere oorzaken volledig kunnen worden uitgesloten. Volgens het hof stond de niet uit te sluiten mogelijkheid dat het slachtoffer ook zonder de handelingen van verdachten zou zijn overleden niet aan toerekening in de weg. In cassatie werd geklaagd dat het hof niet had vastgesteld dat het hoogst onwaarschijnlijk is dat de dood van de juwelier het gevolg is geweest van het hartinfarct. Deze klacht is duidelijk geïnspireerd op de beslissing van de Hoge Raad in de Groninger hiv-zaak.

De Hoge Raad herhaalde de kern van overweging 2.4.4. van het Groninger hivarrest. Maar nu bleef cassatie achterwege. Volgens de Hoge Raad was het oordeel van het hof toereikend gemotiveerd. In de overwegingen van het hof lag immers niet alleen besloten dat de gedraging van verdachte een onmisbare schakel kan hebben gevormd in de gebeurtenissen die tot de dood hebben geleid, maar ook dat het gevolg met een aanzienlijke mate van waarschijnlijkheid door die gedraging is veroorzaakt. Dat is niet onbegrijpelijk als men in aanmerking neemt dat de gedraging van verdachte naar haar aard geschikt is om dat gevolg teweeg te brengen en bovendien naar ervaringsregels van dien aard is dat zij het vermoeden wettigt dat zij heeft geleid tot intreden van het gevolg. Bovendien heeft het hof het 'lichte hartinfarct' voor zover dit al niet het gevolg zou zijn geweest van het bewezenverklaarde gedrag, als niet meer dan een 'niet uit te sluiten' oorzaak beoordeeld. ${ }^{91}$

In deze zaak lagen de alternatieve oorzaak en de door het hof aangenomen oorzaak inderdaad in tijd dicht op elkaar en konden ook beide aan gedragingen van verdachten worden gelinkt. Opmerkelijk is wel dat de Hoge Raad in de laatste zaak genoegen neemt met het oordeel van het hof dat de alternatieve oorzaak niet meer

9I HR I9 maart 2013, ECLI:NL:HR:20I3:BZ449I. A-G mr. Vegter had er nog in het bijzonder op gewezen dat uit het rapport van de patholoog was gebleken dat het kleine hartinfarct ten tijde van het uitgeoefende geweld enige uren oud zal zijn geweest en dat de hartslag waarschijnlijk is gestaakt kort na het oplopen van het nekletsel. Dit temporele verband was volgens de A-G bijzonder relevant nu de contra-indicaties klaarblijkelijk door het hof als veel te zwak zijn beoordeeld. 
dan een 'niet uit te sluiten' oorzaak is geweest, waar in de Groninger hiv-zaak de Hoge Raad vernietigde omdat het hof niet had vastgesteld dat het hoogst onwaarschijnlijk was dat het gevolg door de alternatieve oorzaak is teweeggebracht. Ook opvallend is dat de Hoge Raad niet uitdrukkelijk aandacht besteedt aan een significant verschil tussen beide zaken, te weten dat het opzet van verdachte in de Groninger hiv-zaak erop was gericht om de slachtoffers met hiv te besmetten, terwijl in de andere zaak de dood het kwalificerend gevolg was van het geweldsdelict.

\subsection{Discussies over de condicio sine qua non}

Het Groninger hiv-arrest heeft de leer van de condicio sine qua non weer in het middelpunt van de belangstelling geplaatst. In 2007 bepleitte Kwakman al om de condicio sine qua non centraal te stellen bij de beoordeling van het causaal verband. Zijn uitgangspunt is dat de vraag naar causaliteit voorafgaat aan de vraag naar strafrechtelijke aansprakelijkheid. ${ }^{92}$ Alle uitgangspunten die de relevante juridische oorzaken proberen aan te wijzen hebben volgens deze auteur geen plaats in het domein van de causaliteit, maar horen thuis bij de overige voorwaarden voor strafbaarheid. De vraag naar het causaal verband moet uitsluitend beantwoord worden aan de hand van de condicio sine qua non. Als die vraag is beantwoord moet de causaliteit verlaten worden en dient de vraag te worden gesteld of dit geconstateerde causaal verband wel relevant is. Kwakman roert in zijn bijdrage wel problemen aan van de causaliteit van het nalaten en de dubbele veroorzaking, maar geeft geen antwoord op de vraag hoe het nalaten iets kan veroorzaken en hoe in geval van dubbele veroorzaking buiten de deelneming om er toch strafrechtelijke aansprakelijkheid kan ontstaan. Hij schrijft wel dat er zijns inziens wel degelijk een causaal verband tussen het nalaten en een bepaald gevolg kan bestaan, maar de onderliggende argumentatie acht ik niet overtuigend. Hij schrijft immers: 'Als een kind dat aan de zorg van zijn ouder is toevertrouwd, vanwege ondervoeding komt te overlijden, en de ouder blijkt te hebben nagelaten het kind te voeden, dan is er (...) een causaal verband tussen het nalaten van de ouderen de dood van het kind.' Dit is geen argument, maar een herhaling van een ingenomen positie.

Kwakman heeft zijn standpunt nogmaals uiteengezet naar aanleiding van de uitspraken van rechtbank en hof in de Groninger hiv-zaak. Het hof heeft volgens hem de vraag of er sprake is van een condicio sine qua non onderdeel gemaakt van de vraag of het gevolg redelijkerwijs aan verdachte kon worden toegerekend. ${ }^{93}$ De rechtbank had beide vragen wel van elkaar gescheiden, geen condicio sine qua non-verband aangenomen en slechts voor poging tot zware mishandeling veroordeeld. Het hof veroordeelde wel voor het toebrengen van zwaar lichamelijk letsel maar volgens Kwakman op basis van een ondeugdelijke motivering. Het hof lijkt namelijk de mogelijkheid dat de hiv-besmetting is opgelopen anders dan door de handelingen van verdachten te erkennen, maar van oordeel te zijn dat dit aan de

92 N.J.M. Kwakman, De causaliteit in het strafrecht, NJB 2007, nr. I6, p. 992 e.v.

93 N.J.M. Kwakman, De Groningse HIV-zaak. Vaststellen of toerekenen, dat is de kwestie, DD 2010/43. 
veroordeling voor zware mishandeling niet in de weg staat. Als de wetgever van oordeel zou zijn dat een veroordeling voor een strafbare poging tot zware mishandeling geen recht doet aan de ernst van de gedragingen van verdachten, ligt het op zijn weg om bijvoorbeeld te voorzien in een strafbaarstelling van 'deelplegen', waardoor men strafrechtelijk verantwoordelijk wordt voor gevolgen waarvan het eigen handelen geen condicio sine qua non is en waarin de deelnemingsregeling niet voorziet.

Kwakman schreef zijn bijdrage over de Groninger hiv-zaak voordat de Hoge Raad daarin arrest wees. Witjens heeft wel van het arrest kennis kunnen nemen. ${ }^{94}$ Witjens herhaalt dat empirische causaliteitsoordelen geen zekerheid kunnen bieden omdat zij in het individuele geval zich slechts in waarschijnlijkheid kunnen uitdrukken. ${ }^{95}$ De formule van de condicio sine qua non biedt een schijnzekerheid. Waar het bij de redelijke toerekening echter om gaat, is welke mate van waarschijnlijkheid daarvoor nodig is. Volgens Witjens heeft de Hoge Raad in de Groninger hiv-zaak de eis van de condicio sine qua non laten vallen. Hij leest het arrest aldus dat volgens de Hoge Raad het hof onvoldoende inzichtelijk heeft gemaakt waarom het van oordeel is dat de mogelijkheid van besmetting zich ook in dit geval daadwerkelijk als gevolg van de handelingen van verdachten heeft verwezenlijkt. Welke mate van waarschijnlijkheid nodig is in vergelijkbare gevallen is volgens Witjens nog onduidelijk. Het had zijns inziens overigens voor de hand gelegen dat de Hoge Raad de weg naar de condicio sine qua non geheel had afgesloten.

Ook Keijzer uit zijn twijfels over de toepassing van de condicio sine qua non. Hij wijst erop dat deze regel moeilijk toe te passen is als empirisch onvoldoende bekend is over de afloop in het gedachtenexperiment. ${ }^{96}$ Evenzo is toepassing moeilijk op intermenselijke causaliteit, waarbij de één de ander dwingt, overhaalt, misleidt. Voorts noemt Keijzer de problemen met de meervoudige veroorzaking, zoals in de Groninger hiv-zaak speelde. Een fundamenteel bezwaar is zijns inziens dat het in het strafrecht gaat om de oorzaak en niet enkel om een voorwaarde, die iets mogelijk maakt. In de ige eeuw is te veel de nadruk gelegd op de fysieke causaliteit. ${ }^{97}$ Die fysieke causaliteit kan een rol spelen in het kader van de vraag naar de mogelijkheid van strafrechtelijke aansprakelijkheid, maar kan daarmee niet gelijk worden gesteld. Keijzer wijst op voorstellen in omringende landen om de condicio sine qua non niet meer die prominente plaats te gunnen die hij tot nu toe heeft gehad. Meer aandacht zou moeten krijgen de strekking van het handelen om een onoorbaar gevaar in het leven te roepen zoals zich dat heeft gerealiseerd. Als dat het geval is, moet strafrechtelijke aansprakelijkheid voor het gevolg worden aangenomen, ook als toepassing van de condicio sine qua non geen zekerheid geeft.

94 E.M. Witjens, Het bewijs van causaal verband in de Groninger HIV-zaak, DD 20I2/35.

95 Dit is volgens mij maar de vraag. Er zijn gevallen waarin zonder enige twijfel vaststaat dat een gedrag een gevolg teweeg heeft gebracht. Denk aan de gruwelijke praktijk van de onthoofding in radicale kringen. Als de beul het hoofd van het slachtoffer afhakt kan iedereen met zekerheid zeggen dat aldus een einde aan een menselijk leven is gekomen.

96 Nico Keijzer, Condicio sine qua non?, in Amicus Curiae. Liber Amicorum Marc de Swaef, Antwerpen-Cambridge 2013, p. 248.

97 Nico Keijzer, Condicio sine qua non?, p. 249. 


\subsection{Bijdenken of wegdenken}

De zaak waarin de HR op I8 mei 2004 arrest wees (NJ 2004, 5I2) verdient in dit verband nog vermelding. Verdachte was met zijn auto tegen een andere auto gebotst waarbij twee inzittenden van de andere auto zijn omgekomen. Verdachte reed $63 \mathrm{~km} / \mathrm{h}$ binnen de bebouwde kom, waar een maximumsnelheid van $50 \mathrm{~km} / \mathrm{h}$ gold en was bovendien onder invloed van alcohol. Het hof sprak vrij van de tenlastelegging van dood door schuld en nam daarbij mede in aanmerking dat naar het oordeel van een deskundige het mogelijk was dat de botsing ook zou zijn ontstaan als verdachte zich aan de maximumsnelheid had gehouden en voorafgaand aan de aanrijding zou hebben geremd of anderszins adequaat zou hebben gereageerd. Volgens de HR gaf de motivering van de vrijspraak geen blijk van een onjuiste rechtsopvatting en was deze evenmin onbegrijpelijk. Van Eck heeft erop gewezen dat zo een redenering niet past binnen de matrix van de condicio sine qua non. Zuivere toepassing van dit criterium verlangt beantwoording van de vraag wat er zou zijn gebeurd als de gedraging van verdachte zou zijn weggevallen. De vraag wordt onzuiver door het gat dat door het wegvallen van de concrete gedraging ontstaat vervolgens te vullen door het bijdenken van een correct gedrag. ${ }^{98}$

\section{$6.4 \quad$ Nalaten}

\section{Literatuur}

Een pijnpunt voor de condicio sine qua non is altijd de vraag geweest of ook het nalaten oorzaak kan zijn: ex nihilo nihil nascitur. Van Eck schrijft dat nalaten nooit een fysieke causa efficiens kan zijn, noch een intentionele causa efficiens, omdat nalaten de aanwezige, werkzame factoren niet bundelt en daaraan geen richting geeft. ${ }^{99}$ Dat vanouds nalaten als causa wordt aangemerkt past niet bij het uitgangspunt van de condicio sine qua non. De causaliteit van het nalaten is een fictie: 'qui non facet quod facere debet, videtur facere adversum ea, quia non facit'. ${ }^{100}$ Ook Witjens wijst op dit probleem. Factoren die geen invloed hebben uitgeoefend spelen in de condicio sine qua non immers geen rol. ${ }^{\text {Ior }}$ Toch wordt aansprakelijkheid voor gevolgen in het civiele recht wel aan nalaten vastgeknoopt via het gevergd handelen, de zorgplicht. Wat zou er gebeurd zijn als men had ingegrepen zoals dat werd gevergd? En kan men wel in voldoende mate het nalaten van het doen onderscheiden, nu er vaak sprake is van een complex van gedragingen van positieve en negatieve aard? ${ }^{102}$ Ook in het strafrecht biedt nalaten de basis voor aansprakelijkheid voor gevolgen. ${ }^{103} \mathrm{Men}$ lijkt zich binnen de kaders van de condicio sine qua non te blijven bewegen door uit

98 Van Eck, Causaliteit en aansprakelijkheid voor gevolgen in het strafrecht, Deel I, p. 234 e.v.

99 Van Eck, Causaliteit en aansprakelijkheid voor gevolgen in het strafrecht, Deel I, p. 83 e.v.

Ioo Van Eck, Causaliteit en aansprakelijkheid voor gevolgen in het strafrecht, Deel I, p. I04.

IOI Witjens, Strafrechtelijke causaliteit, p. 2I. Zie verder p. 83.

I02 Witjens, Strafrechtelijke causaliteit, p. 90 e.v.; G. Knigge, Doen en laten, enige opmerkingen over daderschap, DD i992, p. I28 e.v.

I03 Witjens, Strafrechtelijke causaliteit, p. I77 e.v. 
te gaan van een bijzondere rechtsplicht en van de effecten die het vervullen van die rechtsplicht zou hebben gehad. ${ }^{\mathrm{I} 4}$ Maar strikte toepassing van de condicio sine qua non op nalaten is onmogelijk.

\section{Rechtspraak}

De causaliteit van het nalaten is in de rechtspraak geen onderwerp dat frequent opduikt. Af en toe wordt er in de rechtspraak gezinspeeld op een andere afloop, als wel zou zijn ingegrepen, of wordt erop gewezen dat de afloop niet redelijkerwijs als gevolg van het verzuim van verdachte te verwachten was, ${ }^{105}$ maar zulke zinspelingen zijn uitzondering. Dat is niet onbegrijpelijk, omdat in de meeste situaties er sprake zal zijn van een combinatie van doen en nalaten waarbij de kracht en invloed van ieder van de componenten moeilijk is vast te stellen.

In HR 30 september 2003, NJ 2005, 69 m.nt. Knigge kwam de vraag naar het causaal verband tussen het overlijden van een kind en het nalaten van verdachte om medische hulp in te roepen aan de orde. Verdachte is ervoor veroordeeld dat hij zijn zoontje van enige maanden oud opzettelijk in een hulpeloze toestand heeft gelaten door, toen het kind er slecht aan toe was, na te laten tijdig adequate medische hulp in te roepen, ten gevolge waarvan het kind is overleden. Bij sectie bleek dat het kind was overleden als gevolg van hersenletsel, passend bij de diagnose 'shaken baby syndrome'. Het letsel moet, evenals de geconstateerde ribbreuken en breuken in het voorhoofdsbeen, het gevolg zijn geweest van geweld. In cassatie werd er over geklaagd dat uit de bewijsmiddelen niet was af te leiden dat het kind vermoedelijk niet zou zijn overleden als wél medische hulp was ingeroepen. Op verdachte rustte volgens de Hoge Raad de plicht om te doen wat in zijn vermogen lag om ervoor te zorgen dat het kind tijdig de nodige medische hulp zou krijgen. Dat heeft hij nagelaten. Het oordeel van het hof dat verdachte het gevaar van het overlijden van het kind zodanig heeft verhoogd dat het overlijden redelijkerwijs aan hem kan worden toegerekend als gevolg van diens nalaten om tijdig medische hulp in te roepen, geeft geen blijk van een onjuiste rechtsopvatting en is evenmin onbegrijpelijk. Niet nodig voor het aannemen van het causaal verband tussen de dood van het kind en het nalaten om medische hulp in te roepen is dat de bewijsmiddelen uitdrukkelijk de mogelijkheid zouden moeten uitsluiten dat ook bij het tijdig inschakelen van medische hulp het kind zou zijn overleden. Annotator Knigge ziet het belang van het arrest er in dat de Hoge Raad zich niet aan een voorspelling waagt van wat er zou zijn gebeurd als de feitelijke situatie anders was geweest. Het enkele feit dat het verzuim het risico van het overlijden van het kind in een bepaalde mate heeft vergroot is voldoende om causaal verband aan te nemen.

In HR I2 maart 20I3, NJ 2013, 423 m.nt. Legemaate wordt de band tussen het nalaten van verdachte en het uiteindelijke gevolg nog verder uitgerekt. Een arts die op alternatieve wijze een vrouw voor borstkanker behandelde, is vervolgd. De patiënte had zich afgekeerd van de reguliere gezondheidszorg toen bij haar borstkanker was

I04 Witjens, Strafrechtelijke causaliteit, p. I79, p. 22 I.

I05 Vgl. Rb. Utrecht I8 januari I949, 665 . 
vastgesteld. Uiteindelijk is de patiënte in een deplorabele en terminale toestand toch in het ziekenhuis opgenomen, waar zij is overleden. De arts is veroordeeld voor mishandeling, omdat hij opzettelijk de gezondheid van de vrouw heeft benadeeld door na te laten haar tijdig te verwijzen naar geneeskundigen die binnen de reguliere gezondheidszorg haar palliatief zouden kunnen behandelen, ten gevolge waarvan zij zwaar lichamelijk letsel - kort gezegd zeer ernstige ziekteverschijnselen - heeft bekomen. In cassatie werd geklaagd dat het hof ten onrechte causaal verband heeft aangenomen tussen het doen en laten van verdachte en het zwaar lichamelijk letsel. Het hof had geoordeeld dat niet valt uit te sluiten dat een verwijzing door verdachte naar de reguliere gezondheidszorg ter bestrijding van de pijn en andere nadelige gezondheidseffecten meer zou hebben geholpen dan de pogingen die andere artsen daartoe al hadden aangewend. Volgens het hof was het feit dat de patiënte die palliatieve reguliere therapieën niet heeft ondergaan het in redelijkheid aan verdachte toe te rekenen gevolg van het feit dat verdachte zijn zorgplicht heeft geschonden als arts. ${ }^{\text {I06 }}$

Volgens A-G Knigge had het hof aldus te zwakke eisen gesteld aan het causaal verband. De Hoge Raad overwoog dat het achterwege laten van stappen om de verslechtering van het ziektebeeld van patiënte zo veel mogelijk te bestrijden niet als verantwoorde zorg kan worden aangemerkt. De geneesheer die te maken krijgt met een patiënte die een aangewezen reguliere behandelwijze afwijst, moet deze patiente informeren over de consequenties. In dit geval is vastgesteld dat de arts heeft nagelaten de patiënte, die haar vertrouwen in hem had gesteld, adequaat, indringend en herhaaldelijk te stimuleren om haar heil bij de reguliere geneeskunde te zoeken. Niet uit te sluiten is dat zo een optreden van verdachte bij de patiënte meer effect zou hebben gehad dan pogingen van andere artsen. Het oordeel van het hof dat verdachte door zich zo te gedragen het gevaar van het bewezenverklaarde letsel in zodanige mate heeft verhoogd dat dit letsel aan verdachte kan worden toegerekend als gevolg van zijn nalaten om tijdig toereikende medische zorg te bieden, geeft geen blijk van een onjuiste rechtsopvatting.

\subsection{Intermenselijke/interactionele veroorzaking}

In zijn bijdrage aan het liber amicorum voor Marc de Swaef wijst Nico Keijzer ook op de moeilijkheden waarop de condicio sine qua non stuit bij delicten die een beïnvloeding van de ene mens door de ander vergen. Denk aan de oplichting, artikel 326 Sr. De praktijk leert dat dit causaal verband daar vaak wordt aangenomen op basis van een aangifte waarin de gedupeerde vermeldt dat hij niet zou zijn overgegaan tot afgifte als hij had geweten dat hij werd bedrogen. Aldus wordt er getracht een link

Io6 In HR I6 mei I995, NJB I995, nr. 99, p. 4I3 deed zich een vergelijkbare zaak voor. Het betrof een iatrosofisch arts die was veroordeeld voor het toebrengen van zwaar lichamelijk letsel aan een patiënte door het onthouden van adequate medische verzorging. Ook deze patiënte had zich verzet tegen een gewone kuur met antibiotica en opname in het ziekenhuis. Het nadien opgetreden zwaar lichamelijk letsel kon aan verdachte worden toegerekend hoewel patiënte zelf de behandeling met antibiotica en opname in een ziekenhuis had geweigerd, omdat de patiënte daarbij onder invloed stond van verdachte. 
te leggen naar een condicio sine qua non. Maar helemaal zuiver is deze verbinding niet. De vraag zou immers moeten luiden of aangever ook zou hebben afgegeven als de gedraging van de verdachte wordt weggedacht en niet of er ook zou zijn afgegeven als er iets bij wordt gedacht, bijvoorbeeld wetenschap over de bedrieglijkheid van het gedrag van de ander. Alleen in die gevallen waarin de een zich al had voorgenomen het goed aan de ander af te geven, bijvoorbeeld het betalen van geld ter delging van een schuld, zal het bedrog van de crediteur met de bedoeling de ander tot betaling te bewegen geen condicio sine qua non kunnen zijn. De juiste vraag die aan de gedupeerde moet worden gesteld is dus of hij al van plan was om het goed af te geven zonder enigerlei tussenkomst van verdachte. Als de vraag zo wordt gesteld zal het condicio sine qua non-verband slechts uiterst zelden ontbreken. Ter illustratie wijs ik op HR 3 mei 1994, DD 94.328 waarin de VS de uitlevering verzochten van een persoon wegens betrokkenheid bij oplichting. De oplichting zou erin hebben bestaan dat decoders werden gemanipuleerd zodat satellietsignalen konden worden opgevangen zonder daarvoor abonnementsgeld af te dragen, waardoor de verzender van de signalen zou zijn opgelicht. Maar de Hoge Raad stelde vast dat niet was gebleken dat het gebruik van die decoders heeft geleid tot andere dan de al gebruikelijke activiteiten van de verzender van die signalen. Daarom kan het gebruik van de verkochte decoders niet als 'bewegen' in de zin van artikel $326 \mathrm{Sr}$ worden uitgelegd. ${ }^{\text {107 }}$

Als men aanneemt dat rechtspersonen die bijvoorbeeld geldautomaten exploiteren, kunnen worden gebracht tot afgifte van geld aan iemand die een valse pas invoert, zal ook in zo'n geval bijna altijd sprake zijn van een condicio sine qua non voor de afgifte. Immers, als het gedrag van de verdachte achterwege zou zijn gebleven zou dat geld niet op dat moment aan hem zijn uitgekeerd. ${ }^{\text {108 }}$

Toepassing van de condicio sine qua non voor de uitleg van het bestanddeel 'bewegen' verschaft dus geen enkele duidelijkheid omdat in bijna alle gevallen het handelen van verdachte daaronder zal kunnen worden begrepen. De laatste jaren acht de Hoge Raad alle omstandigheden van het geval van belang voor de vraag of er bewogen is:

'Tot die omstandigheden behoren de vertrouwenwekkende aard, het aantal en de indringendheid van de (geheel of gedeeltelijk) onware mededelingen in hun onderlinge samenhang, de mate waarin de in het algemeen in het maatschappelijk verkeer vereiste omzichtigheid degene tot wie de mededelingen zijn gericht aanleiding had moeten geven de onwaarheid te onderkennen of zich daardoor niet te laten bedriegen en de persoonlijkheid van het slachtoffer. ${ }^{\prime 109}$

Ook deze aanwijzing geeft nog geen scherpe grens. Relevant zijn dus de kracht van het bedrog, de gewoonlijk te betrachten voorzichtigheid om te voorkomen dat men te snel slachtoffer wordt van bedriegers, maar ook de persoonlijkheid van het slachtoffer omdat nu eenmaal de één door gebreken, leeftijd, ontwikkeling, een

I07 Zie ook HR 29 november I994, NJB I995, nr. 27, p. 93.

Io8 HR ig november I99I, NJ I992, I24.

I09 HR I5 november 20II, NJ 20I2, 279 m.nt. Reijntjes; HR I3 november 20I2, ECLI:NL:HR: 20I2:BXo8o6; HR 4 februari 20I4, ECLI:NL:HR:20I4:236; HR Iojuni 20I4, ECLI:NL:HR:20I4:I366. 
makkelijker prooi van bedriegers zal zijn dan een ander en het strafrecht ook degene die zwakker in zijn schoenen staat dient te beschermen tegen de kwade bedoelingen van anderen. Ervaringsgegevens worden dus gecombineerd met normatieve eisen, die per geval kunnen verschillen.

Ook in andere delictsomschrijvingen heeft de wetgever gebruikgemaakt van het woord 'bewegen'. Ik wijs op artikel $248 \mathrm{a}$ Sr dat het door aangewezen middelen bewegen tot ontucht van iemand die jonger is dan 18 jaar strafbaar stelt. Artikel 248d Sr stelt, kort gezegd, strafbaar het bewegen van een persoon jonger dan 16 jaar tot het getuige zijn van seksuele handelingen. Artikel $273 \mathrm{f} \mathrm{Sr}$ kent verschillende onderdelen waarin 'bewegen' of 'ertoe brengen' strafbaar is gesteld. Een van die onderdelen, lid I sub 5 , stelt strafbaar het iemand die de leeftijd van 18 jaar nog niet heeft bereikt ertoe brengen zich beschikbaar te stellen tot het verrichten van seksuele handelingen tegen betaling. De Hoge Raad is van oordeel dat onder het 'tot prostitutie brengen' mede dient te worden begrepen iedere gedraging gericht tegen een persoon die ertoe strekt deze te belemmeren in zijn vrijheid om met prostitutie op te houden, ongeacht of deze persoon vrijwillig bij prostitutie betrokken is geraakt dan wel eerder reeds bij prostitutie betrokken was. Niet nodig is dat de mogelijkheid om een reële eigen keuze te maken voor de prostituee beperkt is. ${ }^{\text {Io }}$

Ik maak uit een en ander op dat de context waarin het 'bewegen' strafbaar is gesteld en de belangen die de strafbaarstelling dient, relevant zijn voor de invulling ervan. Bij de zedendelicten gaat het om de bescherming van de minderjarigen, zelfs zijns of haars ondanks. Iedere gedraging die erop is gericht prostitutie door de minderjarige gemakkelijker te maken of te bevorderen lijkt mij onder artikel $273 \mathrm{f} \mathrm{lid} \mathrm{I}$ sub $5 \mathrm{Sr}$ te vallen. Er hoeft geen misleiding aan te pas te komen, hoewel dat wel kan. Bij artikel $326 \mathrm{Sr}$ is misleiding nu juist de kern van het 'bewegen'.

Ook treffen we in een groot aantal delictsomschrijvingen het bestanddeel 'dwingen' aan. Ook dat woord duidt op een beïnvloeding van de een door de ander, op het veroorzaken van een bepaald gedrag. Ook hier is sprake van een intermenselijke causaliteit. De meeste rechtspraak heeft betrekking op de artikelen 242 en $246 \mathrm{Sr}$, respectievelijk de verkrachting en de aanranding. De gebruikelijke omschrijving van het dwingen tot het ondergaan, plegen of dulden van de in die artikelen genoemde gedragingen is dat de dader door een middel zoals in die artikelen omschreven opzettelijk veroorzaakt dat het slachtoffer tegen zijn of haar wil die handelingen heeft ondergaan. ${ }^{\text {III }}$ Dat veroorzaken kan door het aanwenden van fysieke kracht, maar ook door het oproepen van een zodanige dreiging dat de vrees van het slachtoffer voor geweld gerechtvaardigd is. ${ }^{\text {II2 }}$ Voor de vraag of van 'dwingen' sprake is, zal acht moet worden geslagen op de verhouding tussen dader en slachtoffer, op de persoonlijke omstandigheden en kenmerken van beiden, zoals leeftijd, kwetsbaarheid, afhankelijkheid, gevoeligheid van het slachtoffer, dominantie, gezag,

IIo Bijv. HR ro september 20I3, ECLI:NL:HR:20I3:669; HR 20 mei 20I4, ECLI:NL:HR:20I4:II74.

III HR 29 november 1994, NJ I995, 20I; HR 24 maart I998, NJ I998, 534 m.nt. de Hullu.

II2 HR I3 juni I995, NJB I995, nr. I03, p. 430. 
angstaanjagendheid van de dader. ${ }^{113}$ Van een absolute onmogelijkheid voor het slachtoffer om zich te verzetten hoeft geen sprake te zijn. Het slachtoffer kan ook zodanig onder de indruk zijn van het optreden van verdachte dat in redelijkheid niet gevergd mocht worden dat het slachtoffer zou trachten zich aan verdachte te onttrekken. ${ }^{\mathrm{II}}$ In geval van jarenlange intimidatie en onderdrukking is het moeilijk om een enkele gedraging van verdachte te identificeren als de condicio sine qua non van het toegeven van het slachtoffer. Dikwijls zal er sprake zijn van een patroon van gedragingen die de strekking hebben het slachtoffer te onderwerpen, zonder dat van iedere gedraging afzonderlijk de veroorzakende kracht kan worden vastgesteld. Van een absolute onmogelijkheid voor het slachtoffer om zich te verzetten hoeft geen sprake te zijn. ${ }^{\text {I5 }}$

Ook bij bijvoorbeeld afpersing (artikel $317 \mathrm{Sr}$ ) moet sprake zijn van dwingen, meestal tot afgifte. Het slachtoffer maakte in zo'n geval de keuze, die evenwel niet in vrijheid tot stand is gekomen. In de meeste gevallen zal hier geen sprake zijn van een gezamenlijk verleden tussen dader en slachtoffer, maar de levenservaring, ontwikkeling, vaardigheden en de leeftijd van het slachtoffer kunnen wel van belang zijn voor de beantwoording van de vraag of er inderdaad is gedwongen tot afgifte. Als een geoefende commando te maken krijgt met iemand die met een zakmes dreigt zal voor hem eerder een alternatief voorhanden zijn voor het afgeven van zijn portemonnee dan wanneer het gaat om een oude dame. Bedreiging met het zakmes zal condicio sine qua non zijn als inderdaad de beurs wordt afgegeven, zowel in het ene als het andere geval, maar de vraag rijst wel of de commando dan gezegd kan worden te zijn gedwongen. Hetzelfde geldt bijvoorbeeld wanneer een bankbediende overgaat tot afgifte van geld aan een overvaller die ermee dreigt een koffiekopje tegen de muur kapot te gooien tenzij men hem ter wille is.

Bij veroorzaking van menselijk gedrag door ander menselijk gedrag spelen op het eerste gezicht andere factoren dan natuurwetenschappelijke een belangrijke rol. Zo zal gelet worden op wat redelijkerwijs nog gevergd kan worden van iemand van leeftijd, ervaring en bekwaamheden als het slachtoffer. In de kern genomen gaat het erom of het voor de rechter begrijpelijk is en invoelbaar dat het slachtoffer heeft toegegeven, dat het zich gedwongen heeft gevoeld om de dader terwille te zijn. Omschrijvingen dat het gevolg, te weten het toegeven van het slachtoffer, redelijkerwijs aan verdachte is toe te rekenen heb ik niet aangetroffen. Maar de causaliteitsvraag, die besloten ligt in woorden als 'bewegen' of 'dwingen', is bij deze strafbaarstellingen onmiskenbaar normatief ingevuld.

II3 HR io oktober 2006, NJ 2006, 624 m.nt. Buruma.

II4 Bijv. HR 27 augustus 2013, ECLI:NL:HR:2013:494.

II5 HR I6 november I999, NJ 2000, I25. 


\section{$7 \quad$ Het Algemeen Deel van het Wetboek van Strafrecht}

\section{I Uitsluiting en verhoging van strafbaarheid}

Titel III van het Eerste Boek van het WvS draagt de naam 'Uitsluiting en verhoging van strafbaarheid' en beslaat de artikelen 39 tot en met 44. Zij bevat de strafuitsluitingsgronden (artikel $39 \mathrm{t} / \mathrm{m}$ 43) en enige verder in dit kader niet relevante mogelijkheden van strafverhoging.

Opvallend is dat de wetsgeschiedenis van de bepalingen over uitsluiting van de strafbaarheid zich concentreert op de toerekening. Geen strafrechtelijke verantwoordelijkheid zonder toerekenbaarheid van het feit aan de dader. Geen toerekenbaarheid waar de vrijheid van handelen, de keus tussen het doen of laten van wat de wet verbiedt of gebiedt is uitgesloten, of waar de dader het ongeoorloofde van zijn handelingen niet kon beseffen en de gevolgen ervan niet kon voorzien. In de voorstelling die de wetgever zich maakte van wat wij thans de strafuitsluitingsgronden noemen, is een vooraanstaande plaats ingeruimd voor de verantwoordelijkheid van het individu, samenhangend met de mogelijkheid die de persoon heeft om een keuze te maken uit alternatieven. Deze voorstelling wordt vormgegeven met behulp van bewoordingen die verwijzen naar causaliteit, zoals 'oorzaken', 'gevolgen', 'ten gevolge van' enzovoort. Maar nergens wordt verwezen naar vragen van causaliteit of naar theorieën over causaliteit. Het lijkt erop dat voor de wetgever de gronden voor uitsluiting van strafbaarheid onderwerpen zijn die slechts nopen tot een onderzoek of het strafbaar feit kan worden toegerekend vanwege de keuze die de persoon in vrijheid heeft gemaakt. Die toerekenbaarheid kan ontbreken door oorzaken in de persoon zelf gelegen, of in van buiten komende oorzaken. ${ }^{\mathrm{I16}}$ Volgens de Memorie van toelichting zijn de abnormale toestand van de geestvermogens en de jeugdige leeftijd de inwendige oorzaken van ontoerekenbaarheid, overmacht, noodweer, wettelijk voorschrift en ambtelijk bevel de uitwendige oorzaken. Het rechtssubject waarvan de wetgever uitging, is de mens die vrij is om anders te handelen en die in staat is om zijn wil te bepalen.

Artikel $39 \mathrm{Sr}$

Wetsgeschiedenis

In het kader van de bespreking van de voorganger van het huidige artikel $39 \mathrm{Sr}$, het voorgestelde artikel $37 \mathrm{Sr}$, dat betrekking had op de geestelijke toestand van de verdachte, sprak de Minister van 'veroorzaakt', 'oorzaken', 'gevolg'. Hetzelfde deed de voorgestelde wettekst. In het oorspronkelijke ontwerp luidde het artikel aldus:

'Niet strafbaar is hij die een feit pleegt, terwijl hij ten gevolge hetzij van den toestand van bewusteloosheid waarin hij verkeert, hetzij van de gebrekkige ontwikkeling of ziekelijke storing zijner geestvermogens, buiten staat is ten aanzien van dat feit zijnen wil te bepalen.'

II6 Mr. H.J. Smidt, Geschiedenis van het Wetboek vam Strafrecht, Haarlem I88I, Eerste Deel, p. 339. 
Aldus was het verband tussen de oorzaken van niet-toerekening en de wilsbepaling ondubbelzinnig uitgedrukt. ${ }^{117}$ De geestelijke toestand van de verdachte heeft tot gevolg dat hij niet in staat is vrijelijk zijn wil te bepalen, hetgeen weer leidt tot niet-strafbaarheid. Ingaande op kritiek van de Kamercommissie en van deskundigen herformuleerde de Minister de tekst. In die nieuwe redactie is het huidige artikel 39 Sr duidelijk zichtbaar. De nieuwe redactie verklaarde niet strafbaar degene die een feit heeft begaan dat hem - kort gezegd - wegens zijn geestelijke gebreken of toestand niet kan worden toegerekend. Zo wilde de Minister voorkomen dat de wetgever zich te veel in psychologische of psychiatrische vraagstukken moest verdiepen. ${ }^{\mathrm{II} 8}$ De mondelinge beraadslagingen in de Tweede Kamer concentreerden zich op de bewusteloosheid als oorzaak van niet-toerekening en geven verder geen verduidelijking over de achtergrond van deze koerswijziging.

Hoe de wetgever het verband tussen toerekening en het bestaan van een geestelijke handicap heeft gezien is niet erg helder. Wel is duidelijk dat dit verband loopt via de aantasting van de vrije wil/wilsbepaling maar volgens welke criteria kan worden vastgesteld dat de mentale toestand oorzaak is van die aantasting blijft duister.

\section{Literatuur en rechtspraak}

Artikel 39 Sr heeft veel pennen in beweging gebracht. Veel auteurs hebben zich gebogen over het verband tussen stoornis en toerekening. ${ }^{119}$ Er moet volgens Remmelink een ziekte of gebrek in psychiatrische zin aanwezig zijn en dit gebrek of deze ziekte moet een bepaalde psychische toestand doen ontstaan waardoor het feit niet meer kan worden toegerekend. ${ }^{\mathrm{I} 20}$ Het delict was voor verdachte onvermijdbaar vanwege diens geestelijke toestand. ${ }^{221}$ Remmelink volgt hierin Nieboer die betoogt dat uitgangspunt de persoonlijke verantwoordelijkheid is, maar dat er een causaal verband kan bestaan tussen een psychische afwijking en het delict. Hoe groter het aandeel van de afwijking, des te geringer de toerekening, zij het dat het verband door de kracht der redelijkheid niet rechtlijnig verloopt. ${ }^{\text {I22 }}$

De Hullu wijst er nog nadrukkelijk op dat de toerekening van artikel $39 \mathrm{Sr}$ een eigen betekenis heeft die niet samenvalt met de redelijke toerekening bij de causaliteit. ${ }^{23}$ De wetgever is uitgegaan van de verantwoordelijkheid voor wat in vrijheid is begaan. De normale mens staat in het strafrecht centraal. Pas bij wijze van uitzondering kan wegens gebreken aan de wil niet worden toegerekend. ${ }^{22}$ In zo'n uitzonderingsgeval is er sprake van een causaal verband tussen stoornis en het strafbaar

II9 Zie voor beschouwingen over ontoerekeningsvatbaarheid, vrije wil en schuld o.m. M. Otte, Stoornis en straf. Over verbanden tussen wilsvrijheid, schuld en terbeschikkingstelling, DD 2004, 77; A.W.M. Mooij, Handeling, wilsvrijheid en toerekeningsvatbaarheid, DD 2004, 79; A.W.M. Mooij, De toerekeningsvatbaarheid; hoe verder?, DD 20I2, 3.

I20 HSR, p. 284.

I2I HSR, p. 278.

I22 Drs. mr. W. Nieboer, Aegroto Suum, Meppel I970, p. I45. De zgn. imputatiecurve is getekend op p. 200.

I23 De Hullu, Materieel Strafrecht, V.5.I, p. 332.

I24 De Hullu, Materieel Strafrecht, V.5·3, p. 333. 
feit. Alleen zo een causaal verband geeft een probleem bij de toerekening. ${ }^{125}$ Het causaal verband moet dwingend zijn wil het feit niet aan verdachte kunnen worden toegerekend. Met name in geval van compulsieve waanvoorstellingen zal hiervan sprake zijn. ${ }^{\mathrm{I} 26}$ Dat wil niet zeggen dat als zo een causaal verband bestaat er juridisch nooit meer kan worden toegerekend. Het kan immers zijn dat het causaal verband verwijtbaar door verdachte zelf is aangebracht. ${ }^{\mathrm{I} 27}$

Rechtspraak over het verband tussen stoornis en toerekening beperkt zich doorgaans tot de vraag in hoeverre de rechter gebonden is aan het oordeel van deskundigen $^{128}$ en tot de vraag of de toestand waarin verdachte is komen te verkeren niet in die mate aan hemzelf te verwijten is dat een beroep op ontoerekeningsvatbaarheid niet aanvaardbaar is. ${ }^{229}$ Ook wordt met een zekere regelmaat aan de rechter de vraag voorgelegd of in geval van ontoerekeningsvatbaarheid er nog wel sprake kan zijn van opzet of voorbedachte raad. ${ }^{130}$

Artikel 40

Wetsgeschiedenis

Thans luidt artikel $40 \mathrm{Sr}$ dat niet strafbaar is hij die een feit begaat waartoe hij door overmacht is gedrongen. Oorspronkelijk was de tekst van het artikel causaler getoonzet: 'Niet strafbaar is hij die een feit pleegt ten gevolge van overmagt.'

Overmacht is een van de uitwendige oorzaken van ontoerekenbaarheid. ${ }^{13 \mathrm{I}}$ Overmacht is volgens de Minister elke kracht, elke drang, elke dwang waaraan men geen weerstand kan bieden. Deze uitdrukking is volgens de Minister van zo een verpletterende waarheid dat men niet moet proberen het begrip overmacht nader te omschrijven. Als de dwang van dien aard is dat de dader daaraan geen weerstand kon bieden zodat hij alleen ten gevolge daarvan heeft gedaan of nagelaten, is er geen strafbaarheid. Overmacht is dan de drijfveer van het feit, en niet de vrije wilsbepaling van de dader. Het doet er niet toe of de dwang wordt uitgeoefend door derden of gelegen is in de natuur der dingen. ${ }^{\mathrm{I} 2}$ De geraadpleegde taalkundige prof. De Vries meende dat door de oorspronkelijke bewoordingen onvoldoende tot uitdrukking kwam dat de overmacht van buiten moest komen. Hij stelde voor de woorden 'ten gevolge van overmagt' te vervangen door 'daartoe door overmagt gedrongen'. ${ }^{133}$

De discussie tussen Minister en Tweede Kamer over het huidige artikel 40 Sr werd evenwel niet gevoerd naar aanleiding van het voorgestelde artikel, maar in het kader

I25 De Hullu, Materieel Strafrecht, V.5.5, p. 336.

I26 Voorbeelden: HR 9 december 2008, NJ 2009, I57 m.nt. Schalken; HR I6 maart 20Io, ECLI:NL: HR:2010:BK8507; HR 9 oktober 2012, ECLI:NL:HR:2012:BX6734.

I27 De Hullu, Materieel Strafrecht, V.5.4, p. 337. Voorbeeld: HR I2 februari 2008, NJ 2008, 263 m.nt. Keijzer.

I28 Bijv. HR 4 mei I993, DD 93.40I.

I29 HR I6 februari I993, DD 93.3I0; HR I4 december 2004, ECLI:NL:HR:2004:AR3226; HR I2 februari 2008, NJ 2008, 263 m.nt. Keijzer.

I30 HR 24 november I998, NJ I998, I56; HR 5 februari 2008,ECLI:NL:HR:2008:BB4959; HR 9 december 2008, NJ 2009, I57 m.nt. Schalken; HR I6 maart 20I0, ECLI:NL:HR:2010:BK8507.

I3I Smidt, Eerste Deel, p. 375 .

I32 Smidt, Eerste Deel, p. 376.

I33 Smidt, Eerste Deel, p. 377. 
van de voorgestelde strafbaarstelling van bedelarij (het latere artikel $432 \mathrm{Sr}$ ) en de onbevoegde uitoefening van de geneeskunst (het latere artikel $436 \mathrm{Sr}$ ). Tijdens de behandeling van het verbod op bedelen werd namelijk een amendement ingediend waarin het in het openbaar bedelen alleen maar strafbaar zou zijn als dit geschiedde 'buiten noodzaak'. De Kamer discussieerde met de Minister over de vraag of aan de bezwaren die het amendement wilde counteren voldoende werd tegemoetgekomen door het bestaan van artikel $40 \mathrm{Sr}^{\mathrm{I}}{ }^{34}$ Het amendement is overigens hier verworpen. Een amendement van dezelfde strekking is voorgesteld bij de behandeling van artikel $436 \mathrm{Sr}$, de onbevoegde uitoefening van een beroep. Dat amendement had speciaal het oog op het verlenen van geneeskundige hulp in een noodsituatie door een niet bevoegde. Hier keerde de Minister zich niet tegen het amendement, omdat artikel $40 \mathrm{Sr}$ hier geen soelaas zou kunnen bieden. De onbevoegde die geneeskundige hulp biedt in een noodsituatie is daartoe niet gedrongen door overmacht, omdat hij het verlenen van die hulp evengoed had kunnen laten. Er is geen fysieke overmacht en, als het gaat om een wildvreemde, evenmin psychische overmacht. ${ }^{135}$

\section{Literatuur en rechtspraak}

Bij artikel 39 Sr speelt de redelijkheid slechts een uiterst marginale rol. Bij de subjectieve overmacht is er daarentegen wel een sterk normatieve inbedding van het verband tussen de uitzonderlijke omstandigheden waarin verdachte verkeerd moet hebben en het delict. ${ }^{13^{6}}$ De vraag daar is of de verdachte redelijkerwijs in staat moet worden geacht weerstand te bieden en zich niet te laten meesleuren door bijvoorbeeld angst, paniek of schrik. ${ }^{137}$ Van belang voor de beantwoording van die vraag is onder meer de ervaring, de leeftijd en opleiding, de persoonlijkheid van verdachte. ${ }^{13} 8$ Ook de aard en omvang van de schade die de verdachte in zijn emotie dreigt aan te richten kan gewicht in de schaal leggen bij de beantwoording van de vraag of van verdachte redelijkerwijs gevergd kon worden dat hij weerstand zou bieden aan deze emotie, evenals de mogelijkheid van een redelijk alternatief. ${ }^{139}$ Tevens kan de omstandigheid dat verdachte zich zelf heeft gebracht in de situatie waarin druk op hem is uitgeoefend in die afweging worden betrokken. ${ }^{\text {I40 }}$

\section{Artikel 41}

\section{Wetsgeschiedenis}

Het artikel dat een regeling trof voor de noodweer kende aanvankelijk een tweede lid dat niet strafbaar stelde de overschrijding van de grens van noodzakelijke

I34 Smidt, Derde Deel, p. 207 e.v.

I35 Smidt, Derde Deel, p. 228 e.v.

I36 De Hullu, Materieel Strafrecht, V.2.3, p. 29I; G.G.J. Knoops, Psychische overmacht en rechtsvinding, Deventer I998, p. II2 e.v.; M.M. Dolman, Overmacht, Nijmegen 2006, p. I87 e.v.

I37 Bijv. HR 3 juli 200I, NJ 200I, 537; HR 30 november 2004, NJ 2005, 94 m.nt. Mevis.

I38 HR I7 november I987, NJ I988, 809 m.nt. GEM; HR 6 december 20II, NJ 20I2, 59I m.nt. Keulen.

I39 HR I3 juni I989, NJ I990, I93 m.nt. GEM; HR 23 november I999, NJ 2000, 89; HR 6 december 20II, ECLI:NL:HR:20II:BP9394.

I40 HR 6 december 20II, NJ 20I2, 590 m.nt. Keulen. 
verdediging als zij het onmiddellijke gevolg is geweest van vrees, angst of radeloosheid, door de aanranding veroorzaakt. In deze oorspronkelijke tekst is dus een dubbel causaal verband opgenomen. In de eerste plaats het verband tussen de aanranding als oorzaak van vrees, angst of radeloosheid, in de tweede plaats het causaal verband tussen die vrees, angst of radeloosheid en de overschrijding van de grenzen van noodzakelijke verdediging. De Tweede Kamer had enkel bezwaar tegen een limitatieve opsomming in het tweede lid, aan welk bezwaar de Minister tegemoet kwam door deze opsomming te vervangen door de uitdrukking 'hevige gemoedsbeweging'. ${ }^{14 \mathrm{I}}$

\section{Literatuur en rechtspraak}

De aanranding moet een hevige gemoedsbeweging veroorzaken, die op haar beurt weer leidt tot overschrijding van de grenzen. Ook andere factoren dan de aanranding kunnen bijdragen aan het ontstaan van de hevige gemoedsbeweging. ${ }^{142}$ Zo kan de hevige gemoedsbeweging ook gevoed worden door de verontwaardiging vanwege een eerdere belediging. Tevens zal tot op zekere hoogte met de persoonlijke kenmerken van degene die zich verdedigt rekening kunnen worden gehouden. De één raakt misschien wat eerder in paniek dan de ander. De hevige gemoedsbeweging moet op haar beurt wel van doorslaggevend belang zijn geweest voor de gedraging. Als de overschrijding van de grenzen van noodzakelijke verdediging is terug te voeren op een ernstige persoonlijkheidsstoornis is aan deze voorwaarde niet meer voldaan. ${ }^{\mathrm{I} 33}$ Evenmin zal de overschrijding van de grenzen het onmiddellijk gevolg geacht kunnen worden te zijn van een hevige gemoedsbeweging als die overschrijding de grenzen van hetgeen nog redelijk is te achten te buiten gaat. ${ }^{\mathrm{I} 44}$ Een zekere normativering van noodweerexces spreekt ook uit de eisen die worden gesteld uit hoofde van bijvoorbeeld het beroep dat men uitoefent. Van een politieagent in het nauw wordt meer beheersing gevergd dan van een gewone burger. ${ }^{\mathrm{I} 45}$

Het verband tussen aanranding en verdediging kan worden doorbroken door aan de aanranding voorafgegane gedragingen van degene die zich op noodweer beroept. Te denken valt dan aan de situatie waarin de aanrander moedwillig wordt geprovoceerd of waarin degene die zich op noodweer beroept de confrontatie zelf heeft gezocht. ${ }^{\mathrm{I} 46}$ De provocateur handelt niet ter noodzakelijke verdediging. De verdedigingswil ontbreekt. ${ }^{\mathrm{I} 7}$ Zowel een beroep op noodweer als op noodweerexces zal dan falen.

I4I Smidt, Eerste Deel, p. 379 e.v.

I42 HR I3 juni 2006, NJ 2006, 343.

I43 HR I2 december 2006, NJ 2007, 245 m.nt. Keijzer.

I44 De Hullu, Materieel Strafrecht, V.3.5, p. 3I5 e.v.; HR 8 april 2008, NJ 2008, 3I2 m.nt. Keijzer.

I45 Normativering uit dien hoofde past ook bij het eerste lid van art. 4I Sr.

I46 HR 22 februari 20II, ECLI:NL:HR:20II:BO5250.

I47 HR 8 juni 20I0, ECLI:NL:HR:20I0:BK4788; HR I5 november 20II, NJ 20I2, 474 m.nt. Borgers. 


\section{Conclusie}

Bij de gronden voor niet-toerekening heeft de wetgever zich dus wel bediend van termen die gewoonlijk in verband worden gebracht met causaliteit. Maar niet blijkt dat de wetgever aan de gronden voor niet-toerekening enigerlei causaliteitsleer ten grondslag heeft gelegd. Een complicerende factor op dit terrein is dat de gronden voor niet-toerekening gerelateerd zijn aan de beperking of het ontbreken van de wilsvrijheid of van de mogelijkheid om overeenkomstig een vrij wilsbesluit te acteren. Het kan natuurlijk zijn dat het denken over causaliteit aan het einde van de Ige eeuw zozeer is geïnspireerd geweest op de resultaten in de natuurwetenschappen dat voor een beschouwing over causaliteit met betrekking tot een metafysisch begrip als de vrije wil de geesten nog niet rijp waren. Die vrije wil kon beïnvloed zijn en beperkt worden door omstandigheden binnen of buiten de persoon gelegen, maar het vraagstuk van de causaliteit in het recht had eerder betrekking op de gevolgen van menselijk gedrag dan op de oorzaken van menselijk gedrag. Op het laatste terrein stuitte men immers op de gesloten poort van de vrije wil, op een filosofisch verschijnsel dat zich onttrok aan ijzeren wetmatigheden.

Rechtspraak en literatuur hebben verder weinig opheldering gebracht. Wel duidelijk is dat de gronden voor niet-toerekening in meerdere of mindere mate gerelativeerd zijn door normatieve invloeden.

\subsection{Artikel 45 e.v.; niet-voltooiing van het misdrijf}

\section{Wetsgeschiedenis}

Het eerste lid van artikel $45 \mathrm{Sr}$, zoals dat gold tot de invoering van de strafbaarheid van voorbereidingshandelingen bij Wet van 27 januari 1994, Stb. 1994, 60, komt overeen met de in het oorspronkelijke regeringsontwerp voorgestelde tekst:

'Poging tot misdrijf is strafbaar, wanneer het voornemen des daders zich door een begin van uitvoering heeft geopenbaard en de uitvoering alleen ten gevolge van omstandigheden van zijnen wil onafhankelijk niet is voltooid.'

Straffeloosheid wordt in het vooruitzicht gesteld aan de dader die de voltooiing van het misdrijf eigenhandig heeft verhinderd. De link met de causaliteit is hier eveneens prominent. Waar het materieel omschreven misdrijf een gevolg verlangt dat door gedragingen van de verdachte wordt veroorzaakt, is bij de 'vrijwillige terugtred' juist sprake van het uitblijven van een gevolg door een gedraging van de dader zelve, zodat het misdrijf niet voltooid raakt. De straffeloosheid van de vrijwillige terugtred is het positieve spiegelbeeld van de strafbaarheid van het veroorzaken van het gevolg dat het misdrijf voltooit. De toelichting op het oorspronkelijke regeringsontwerp concentreerde zich op de achtergrond van de straffeloosheid ingeval verdachte zelf heeft voorkomen dat het misdrijf voltooid raakt. De Minister wees erop dat in dat geval de misdadige wil toch niet zo een gevaarlijke richting heeft 
genomen dat er reden is voor bestraffing. ${ }^{\mathrm{I} 4} \mathrm{H}$ Het zekerste middel om het misdrijf te voorkomen is straffeloosheid te verzekeren aan hem die uit eigen beweging heeft afgezien van een voortzetting van zijn misdadig plan. ${ }^{149}$ Er ontstond nog een discussie tussen de Commissie van Rapporteurs van de Tweede Kamer en de regering over de noodzaak van het woord 'alleen' in de voorgestelde tekst. De Commissie wilde het woord schrappen omdat anders poging nooit te bewijzen zou zijn. De mogelijkheid zou immers altijd openblijven dat de voltooiing óók ten gevolge van de wijziging van de wil van de dader en dus niet alléén van omstandigheden die van zijn wil onafhankelijk zijn is verhinderd. Maar de Minister verwees naar de Code Pénal, waarin dezelfde eis tot uitdrukking werd gebracht, hetgeen aan veroordelingen niet in de weg heeft gestaan. Om de inmiddels tot stand gekomen rechtspraak niet waardeloos te maken ontraadde de Minister het schrappen van dit woord. ${ }^{150}$

\section{Literatuur en rechtspraak}

Artikel 46b Sr is ingevoerd bij Wet van 27 januari 1994 , Stb. I994, 6o en houdt in dat er geen strafbare voorbereiding of poging is als het misdrijf niet is voltooid ten gevolge van omstandigheden die van de wil van de dader afhankelijk zijn. De dader moet dus zelf de voltooiing van het misdrijf verhinderen, zijn gedrag moet de oorzaak zijn van de niet-voltooiing. Als de oorzaak van de niet-voltooiing elders is gelegen is dus niet aan de eisen van artikel $46 \mathrm{~b}$ Sr voldaan. ${ }^{151}$ Dat wil niet zeggen dat van buiten komende factoren, die mede ertoe hebben geleid dat het misdrijf niet voltooid raakte, steeds aan vrijwillige terugtred in de weg staan. ${ }^{152}$ Zo een factor kan bijvoorbeeld een uitlating van een derde jegens verdachte zijn, die verdachte doet besluiten niet verder te gaan. ${ }^{153}$

Of het misdrijf niet is voltooid door omstandigheden die van de wil van de dader afhankelijk zijn, hangt af van de omstandigheden van het geval. Als voor voltooiing van het misdrijf nog nodig is dat verdachte iets doet, zal het nalaten daarvan doorgaans geschikt zijn om voltooiing van het misdrijf te verhinderen. Maar wanneer verdachte alles heeft gedaan wat nodig is om het misdrijf te voltooien ligt het anders. In zo een geval van een voltooide poging is meestal een optreden van verdachte nodig dat naar aard en tijdstip geschikt is het intreden van het gevolg te beletten. Relevant daarvoor is de waarschijnlijkheid dat het gevolg tussen de uitvoeringshandeling en het optreden ter voorkoming al zou zijn ingetreden. Hoe waarschijnlijker het intreden van het gevolg in die interval is, des te minder reden om vrijwillige terugtred aan te nemen. ${ }^{54}$ Men zou ook kunnen zeggen dat het optreden van verdachte adequaat moet zijn ter verhindering. ${ }^{155}$

I48 Smidt, Eerste Deel, p. 394.

I49 Smidt, Eerste Deel, p. 395.

I50 Smidt, Eerste Deel, p. 396/397.

I5I HR I7 januari 20I2, NJ 20I2, 517 m.nt. Keijzer; HR 4 februari 20I4, NJ 20I4, 205 m.nt. Keijzer.

I52 HR I9 december 2006, ECLI:NL:HR:2006:AZ2I69; De Hullu, Materieel Strafrecht, VI.4.2, p. 408 e.v.; HSR 2.5.I.4, p. 405 e.v.

I53 HR 22 december 2009, ECLI:NL:HR:2009:BJ9244.

I54 HR 3 maart 2009, NJ 2009, 236 m.nt. Keijzer. De Hullu, Materieel strafrecht, VI.4.2, p. 408 e.v.

I55 Bijv.: HR 3 juli 20I2, ECLI:NL:HR:20I2:BW9976. 


\section{Conclusie}

Ook de invulling van de eisen die moeten worden gesteld aan een effectieve vrijwillige terugtred heeft de wetgever dus grotendeels aan rechtspraak en literatuur overgelaten. Hier had de wetgever toch een aanknopingspunt voor nadere beschouwingen over causaal verband tussen menselijk gedrag en verboden gevolgen. Waarschijnlijk ligt het ontbreken van aanwijzingen over de invulling van het causaal verband hier in dezelfde opvatting die de wetgever bij de bijzondere delicten heeft ontvouwd, te weten dat het niet gaat om een rechtskundige kwestie. Literatuur en rechtspraak hebben de taak op zich genomen om het verband tussen niet-voltooiing en gedrag van de dader te ontwikkelen. Het lijkt erop alsof te rade wordt gegaan bij opvattingen die aanhaken bij de waarschijnlijkheid, de strekking, de voorzienbaarheid en dat aldus de adequatieleren hier nog domineren.

\subsection{Artikel 47 e.v.}

\section{Wetsgeschiedenis}

Ook bij de deelneming lijken aanknopingspunten voor vragen over causaliteit voorhanden te zijn. De Memorie van toelichting stelt dat de uitlokker de oorzaak is van het strafbaar feit. Zonder de uitlokker zou het feit niet zijn gepleegd. Daarom is de uitlokker dader en moet hij ook als dader worden gestraft. ${ }^{156}$

Bij de uitlokkingsmiddelen dwang en misleiding merkt de Memorie van toelichting op dat moet worden onderscheiden tussen dwang of misleiding die de toerekenbaarheid uitsluit en dwang of misleiding die niet alle vrijheid van handelen uitsluit. ${ }^{157}$ De auctor intellectualis is verantwoordelijk voor de handelingen die hij opzettelijk heeft bewerkstelligd en de gevolgen daarvan. Over dit laatste onderdeel ontstond nog een dispuut. De Commissie van Rapporteurs bepleitte het schrappen van deze toevoeging. Niemand mag worden gestraft voor wat hij niet gewild heeft of niet heeft kunnen voorzien. ${ }^{158}$ De Minister verzette zich. Daarop stelde de Commissie een amendement voor. Na de woorden 'benevens hare gevolgen' zou moeten worden toegevoegd 'voor zoover zij die hadden moeten voorzien'. 159 Tijdens de beraadslagingen in de Tweede Kamer wees de Minister erop dat het niet nodig is dat de dader zelf de strafverzwarende gevolgen van bijvoorbeeld mishandeling heeft voorzien maar dat zulke gevolgen in het algemeen te voorzien moeten zijn en daarom ook door dader en medeplichtigen voorzien hadden kunnen worden. ${ }^{160}$ De Commissie van Rapporteurs toonde zich tevreden gesteld en het amendement werd ingetrokken. ${ }^{161}$ Ten aanzien van de verantwoordelijkheid van de medeplichtige voor

I56 Smidt, Eerste Deel, p. 405.

I57 Smidt, Eerste Deel, p. 405.

I58 Smidt, Eerste Deel, p. 407.

I59 Smidt, Eerste Deel, p. 408.

I6o Smidt, Eerste Deel, p. 409.

I6I Smidt, Eerste Deel, p. 4I2. 
de gevolgen van het bevorderde misdrijf (artikel 49 lid 4 Sr) geldt hetgeen hiervoor over de uitlokking is geschreven. ${ }^{162}$

\section{Literatuur en rechtspraak}

Bij uitlokking en doen plegen is er sprake van het veroorzaken van andermans gedrag door die ander daartoe te bewegen. ${ }^{{ }^{163}}$ Het betreft interactionele causaliteit waarbij de ene mens de andere mens beïnvloedt en die ook voor bepaalde misdrijven, zoals oplichting, verlangd wordt. Uitlokking verlangt, in de woorden van De Hullu, een psychische omslag bij de benaderde, het bewerkstelligen van een wilsbesluit. ${ }^{164}$ In de tweede helft van de vorige eeuw werd de vraag naar het causaal verband wel beantwoord met een verwijzing naar algemene ervaringsregels. Als de aanwending van het uitlokkingsmiddel naar ervaringsregels van beslissende invloed was op het besluit van de uitgelokte is er voldaan aan de eis van het causaal verband. ${ }^{165}$ Heden ten dage acht De Hullu het criterium van de redelijke toerekening van toepassing. Hij wijst er daarbij op dat de praktijk geen grote problemen ondervindt bij de beantwoording van de vraag naar de causaliteit van het aanwenden van uitlokkingsmiddelen. Vaak is het oorzakelijk verband evident. ${ }^{166}$

Soms kan degene die wordt beschuldigd van uitlokking zich stellen op het standpunt dat de ander al bereid was datgene te doen waarop het opzet van de uitlokker gericht was. Als dat inderdaad aannemelijk is en de uitlokker bij de benaderde geen wilsbesluit meer heeft kunnen bewerkstelligen ontbreekt het causaal verband. ${ }^{167}$ Maar artikel 47 Sr spreekt van uitlokking van het feit, waaruit is af te leiden dat slechts een algemene bereidheid om feiten van een bepaalde soort te plegen aan uitlokking van een concreet en geïndividualiseerd delict niet in de weg staat. ${ }^{168}$

De gedraging van de medeplichtige moet tot gevolg hebben gehad dat het misdrijf van de ander daadwerkelijk is bevorderd of gemakkelijk gemaakt. ${ }^{169}$ Niet nodig is dat zonder de bijdrage van de medeplichtige het misdrijf niet begaan had kunnen worden. ${ }^{170}$ Evenmin dat hetgeen de medeplichtige heeft verricht te kwalificeren is als een adequate causale bijdrage aan het misdrijf. ${ }^{17 \mathrm{I}}$ Omdat de bijdrage van de medeplichtige op grotere afstand staat van het misdrijf en van mindere relevantie is dan de bijdrage van de uitlokker ligt het niet voor de hand om te zeggen dat het misdrijf redelijkerwijs aan de medeplichtige kan worden toegerekend.

I62 Smidt, Eerste Deel, p. 4I4 e.v.

I63 De Hullu, Materieel Strafrecht, VII.3.I, p. 454.

I64 De Hullu, Materieel Strafrecht, VII.4.4, p. 466.

I65 HR 26 februari I957, NJ I957, 452; HR I8 oktober I960, NJ I96I, 4I5 m.nt. WP (duivenbloed).

I66 De Hullu, Materieel Strafrecht, VII.4.4, p. 467.

I67 Bijv. HR 22 februari I977, NJ I978, 38.

I68 HR 8 juli I992, NJB I992, nr. I48, p. 385; HR 29 september I992, NJB I992, nr. I93, p. 489.

I69 HR I5 december I987, NJ I988, 835; HR ro juni I996, NJ I997, 585. De Hullu, Materieel Strafrecht, VII.5.4, p. 475 .

I70 HR I5 december 1987 , NJB i988, nr. 99.

I7I HR 8 januari I985, NJ I988, 6 m.nt. Van Veen. 


\section{Conclusie}

Bij de deelnemingsvormen, meer bepaald bij uitlokking en doen plegen, is een natuurwetenschappelijk georiënteerde causaliteitsbenadering evenmin voor de hand liggend als bij de gronden van niet-toerekening. Bij uitlokking en doen plegen gaat het enerzijds weliswaar om de gevolgen van menselijk gedrag, maar anderzijds ook om de oorzaken ervan. Een glimp van een causaliteitsleer is waar te nemen als de Minister schrijft dat de uitlokker de oorzaak is van een strafbaar feit zonder wie dat feit niet zou zijn gepleegd. Maar daar blijft het bij. In de rechtspraak en literatuur is een duidelijke aansluiting bij de causaliteitsleren te constateren. In de rechtspraak is de redelijke voorzienbaarheid gehanteerd om de uitlokking vorm te geven, in de literatuur wordt wel verdedigd dat het uiteindelijke strafbare feit redelijkerwijs aan de uitlokker kan worden toegerekend.

\section{Nabeschouwing}

Het denken over causaliteit in het Nederlandse strafrecht wordt overheerst door vragen die ontspruiten aan het BD. Het gaat om gevolgen van menselijk gedrag. Aanvankelijk was de vraag naar causaal verband geen rechtsvraag, maar een feitelijke vraag, waarover de Hoge Raad zich niet uitsprak. De Hoge Raad sloot in zoverre aan bij het heersende empirisme en bij het uitgangspunt van de wetgever. In navolging van de civiele kamer wendde de strafkamer van de Hoge Raad in de dertiger jaren van de vorige eeuw de steven. Hij liet vragen van causaliteit niet meer als louter feitelijke kwesties over aan de feitenrechter. Langzaam maar zeker tekende zich een voorkeur af voor een adequatietheorie in de lijn van Träger. Daarmee was ook een normativering van de causaliteitsvraag een feit. In de laatste decennia van de vorige eeuw is deze normativering voortgeschreden doordat, evenals eerder in het civiele recht, de redelijke toerekening als maatstaf oprukte. De ene maatstaf, die van de redelijke voorzienbaarheid, werd ingeruild voor een ander nog elastischer criterium. Dat biedt meer ruimte, maar anderzijds is het toetsingskader van de redelijke toerekening nog diffuus. De vraag is bijvoorbeeld welke omstandigheden en uitgangspunten daarbij in ogenschouw moeten worden genomen. Eerder ontwikkelde lijnen werden overigens wel voortgezet. Doorbreking van het causaal verband door medische complicaties, eigen schuld of lichamelijke kwetsbaarheden van het slachtoffer kreeg nauwelijks voet aan de grond, maar een scherp criterium ontbreekt. Dat de ene tussenkomende omstandigheid wel en de andere niet aan redelijke voorzienbaarheid of redelijke toerekening in de weg staat, lijkt eerder te stoelen op het hanteren van een intuïtief moreel kompas dan op zuiver juridische definities.

Onder de oppervlakte dient de condicio sine qua non nog steeds als fundament. De rechtspraak is tegen grenzen van de condicio sine qua non opgelopen. Ik doel op de gevallen van dubbele causaliteit en van het oorzakelijk nalaten. De uitspraak van de Hoge Raad in de Groninger hiv-zaak heeft zeker niet alle vragen die de Doppelkausalität doet rijzen opgehelderd. Het is nog maar de vraag welke betekenis aan dat arrest moet worden gehecht. Gaat het om een fundamenteel arrest over causaliteit 
of om een toepassing van bewijsrecht? Moet de condicio sine qua non worden bijgezet in het mausoleum van de geschiedenis van het strafrecht?

Dat een gevolg in redelijkheid ook aan een nalaten kan worden toegerekend stuit op weinig tegenstand. Maar de precieze invulling ervan en de plaats van de bijzondere rechtsplicht ontbeert nog scherpte. Ook de interactionele causaliteit is een beetje een vreemde eend in de bijt. Het gaat daarbij om delicten waarbij een ander wordt bewogen, gedwongen, misleid. Het causaal verband tussen het gedrag van de een en het gedrag van de ander is met meer onzekerheid omgeven dan de klassiekers onder de materiële delicten als levensberoving in allerlei varianten en mishandeling met haar strafverzwarende gevolgen.

In het $\mathrm{AD}$ ligt het leerstuk van de causaliteit delicater dan in het $\mathrm{BD}$. De veronderstelde vrije wil van de mens is de spil waar het bij een groot deel van de strafuitsluitingsgronden om draait. Misschien is daarom de ontwikkeling van het denken over causaliteit in het $\mathrm{AD}$ achtergebleven bij de ontwikkelingen in het BD. Zet men causaliteitsvragen in het perspectief van de vrije wil dan constateert men een spanning waarover al bibliotheken zijn volgeschreven. De neurowetenschappen hebben de discussie aangezwengeld. ${ }^{172}$

En nu heb ik niet eens de blik gericht op de verhouding tussen bijvoorbeeld de causaliteit en de wederrechtelijkheid. Men kan zich bijvoorbeeld de vraag stellen of het intreden van een gevolg niet als een strafverzwarende ${ }^{173}$ omstandigheid moet worden gezien die buiten de gedragskwalificatie der wederrechtelijkheid staat. En heeft de aanmerkelijke kans waar het voorwaardelijk opzet op drijft enigerlei relatie met causaliteit?

De causaliteit is zeker een der oudste leerstukken van het strafrecht, maar ook een leerstuk dat volop in ontwikkeling is en ons nog steeds voor leerstellige en praktische problemen stelt.

I72 Zie bijv. Victor Lamme, De vrije wil bestaat niet, Amsterdam 20I3; Jan Verplaetse, Zonder vrije wil, Amsterdam 2012.

I73 Of, bij de culpose delicten, als een strafbaarheidsvoorwaarde, maar afgezonderd van de wederrechtelijkheid. 